This dissertation has been $\quad 65-9346$ microfilmed exactly as received

DEEMA, Prayoon, 1933METABOLISM, STORAGE, AND EXCRETION OF $C^{14}$-ENDOSULFAN IN THE MOUSE. The Ohio State University, Ph.D., 1965 Zoology

University Microfilms, Inc., Ann Arbor, Michigan 
IETABOLISH, STORAGE, AND LCCITIOIT OP $\mathrm{C}^{14}-$ WDOSULFAN IIN THE IOUSTE

\section{DISTART MIIOIJ}

Presented in Partial Fulfillment of the kequirements for the Degree Doctor of Fhilosophy in the Graduate School of the Ohio State University

By

Prayoon Deema, B.Sc., i...S.

$* * * * *$

The Ohio State University

1965

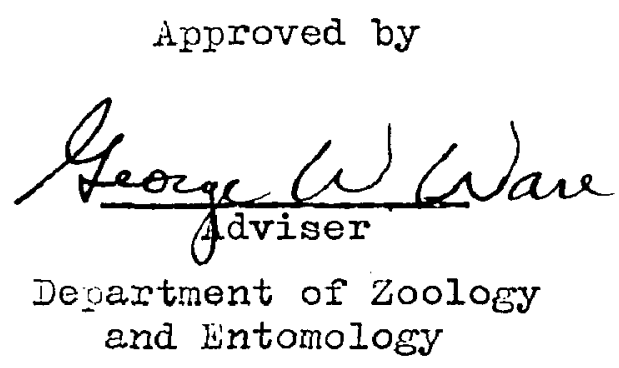


ACKNOWLEDGIIINT

I wish to express my most sincere appreciation and gretitude to my adviser, Dr. George W. Ware, for his guidance, suggestions, criticisms, and encouragement during the course of this investigation. I also would like to thank Dr. George F. Shambaugh and Dr. Frank i. Fisk for their criticisms and sugfestions while preparing this dissertation and Dr. Thomas J. Byers and Dr. J. William A. Burley for their help.

Appreciation and thenks are also extended to the Ohio Agricultural Experiment Station which employed me on the North Central States Regional Project NC-33, during the time I studied at the Obio State University from 1962 to 1964.

I am especially indebted to the Niagara Chemical Division, Food Nachinery and Chemical Corporation, iliddleport, New York, for supplying both the $\mathrm{c}^{14}$-endosulfan ard unlabeled endosulfan derivatives used in this study.

Lastly I would like to thank my wife, Wualchantra, for her patience, encouragement, and understanding. 
CONTENTS

Page

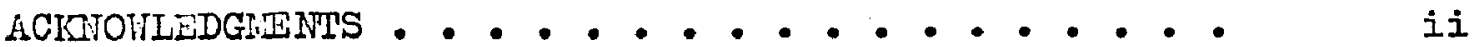

IIIUSTRATIONS . . . . . . . . . . . . . .

TABLES ......................... . $\quad$ v

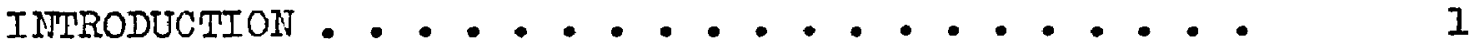

MATERIAIS AND METHODS . . . . . . . . . . . 5

Description of test compounds . . . . . . .

Standard Solutions ................

Metabolism studies of unlabeled endosulfan . . . 7

Extraction procedures of unlabeled endosulfan . . 15

jietabolism studies of $\mathrm{C}^{14}$-egdosulfan . . . . . . 16

Extraction procedures of $\mathrm{C}^{14}$-endosulfan ..... 19

Paper chromatography .. . . . . . . . . 26

Gas chromatography . . . . . . . . . . 29

Thin-layer chromatography . . . . . . . . 30

Autoradiography . . . . . . . . . . . . 32

RESULTS UIND DISCUSSION . • • • • • • • • • • 34

CONCLUSIONS . . . . . . . . . . . . . 67

AUTOBIOGRAPHY . . . . . . . . . . . . . . . 69

IITERATURE CITED . . . . . . . . . . . . . 70 
1. The structures of endosulfan and related chemicals..............

2. The stainless steel rearing cage . . . 6

3. The ISCO lodel M microapplicator . . . 9

4. The Roth metabolism cage, modified to accomodate the laboratory mouse. . . . 10

5. The laboratory pellet mill . . . . . 14

6. Apparatus used in the studies of $\mathrm{C}^{14}$-endosulfan metabolism in the mouse......

7. A tri-carb liquid scintillation spectrometer model 3314 . . . . . . . . . . •

8. Apparatus for $\mathrm{C}^{14} \mathrm{O}_{2}$ production by Van Slyke procedure .... . . . . . . . .

9. Paper chromatograph trace of $5 \mu g$ quantities of endosulfan standards . . . . . . .

10. Gas chromatogram of endosulfan isomers and related products...........

11. Decrease in radioactivity as shown in liquid scintillation due to settling of the sample in the vial ( $\mathrm{Na}_{2} \mathrm{SO}_{4}$ :feces) .......

12. A chromatogram trace of $2 \mu \mathrm{l}$ of fecal extracts from a female mouse after ingesting $10 \mathrm{ppm}$ endosulfan treated food for 28 days. 


\section{TABLES}

Table

Page

1. $R_{f}$ values of technical endosulfan and related dérivatives using reverse phase ascending paper chromatography . . . . . . . . .

2. Radioactivity found in organ extracts, respired $\mathrm{CO}$, urine and feces 24 hours following oral dose of $\mathrm{C}^{14}$-endosulfan in a mouse. The radioactivity were measured with a tri-carb liquid scintillation model 3314 and a model 6000

Dynacon electrometer . . . . . . . . .

3. Radioactivity found in organ extracts, respired $\mathrm{CO}_{2}$, urine, and feces 24 hours following oral dose of $\mathrm{C}^{14}$-endosulfan in a mouse. The radioactivity was measured with a tri-carb liquid scintillation model 3314 . . . . . . . . .

4. Electron capture gas chromatographic analysis of organ extracts from mice sacrificed 12 hours following ingestion of $0.30 \mathrm{mg}$ purified endosulfan .....................

5. Electron capture gas chromatographic analysis of organ extracts from mice sacrificed 24 hours following ingestion of $0.30 \mathrm{mg}$ purified endosulfan ....................

6. Electron capture gas chromatographic analysis of organ extracts from mice sacrificed 24 hours following ingestion of $0.30 \mathrm{mg}$ low-melting point isomer . . . . . . . . . . . .

7. Electron capture gas chromatographic analysis of organ extracts from mice sacrificed 24 hours following ingestion of $0.30 \mathrm{mg}$ high-melting point isomer..................

8. Electron capture gas chromatographic analysis of organ extracts from mice sacrificed after 7 days on $10 \mathrm{ppm}$ endosulfan treated food... 
9. Electron capture gas chromatographic analysis of organ extracts from mice sacrificed after 14 days on 10 ppri endosulfan treated food..

10. Electron capture gas chromatographic analysis of organ extracts from mice sacrificed after 21 days on $10 \mathrm{ppm}$ endosulfan treated food . .

1I. Electron capture gas chromatographic analysis of organ extracts from mice sacrificed after 28 days on $10 \mathrm{ppm}$ endosulfan treated food..

12. Electron capture gas chromatographic analysis of organ extracts from mice sacrificed after 35 days on 10 ppm endosulfan treated food..

13. Electron capture gas chromatographic analysis of organ extracts from mice sacrificed after 42 days on $10 \mathrm{ppm}$ endosulfan treated food..

14. Electron capture gas chromatographic analysis of organ extracts from mice sacrificed after 49 days on $10 \mathrm{ppm}$ endosulfan treated food..

15. $R$ values of technical endosulfan and related derivatives separated by thin-layer chromatography ..................

16. Average daily food consumption of mice fed $10 \mathrm{ppm}$ endosulfan-treated food and the control food ...................... 


\section{INTRODUCTION}

The effectiveness of endosulfan, 6,7,8,9,10,10-hexachloro-1, 5,5a,6,9,9a-hexahydro-6,9-nethano-2, 4, 3-benzodioxathiepin 3-oxide, for the control of wide rango of insect pests of various crops is well recognized (U.S. Dept. Agric. 1964). The potential widespread use of this compound raises a problem concerning the manner in which an animal can detoxify and eliminate the ingested pestioide. The purpose of this investigation was to identify some of the metabolism products of endosulfan in the mouse organs, urine, and feces and to determine whether and where it is stored in animal tissue.

Endosulfan, which has the tride name of Thiodan, was synthesized by Farbwerke Hoechst A.G., Frenkfurt, Gernany, in 1956, and is protected by U.S. Patent 2,799,685 (Farbwerke Hoechst, 1955). It was developed in the United States by the Niagara Chemical Division, Food Hachinery and Chenical Corporation. In the United Kingdom endosulfan is known chemically as $1,2,3,4,7,7$-hexachlorobicyclo $(2,2,1)-2$-hepten 5,6-bis (hydroxymethylen)-sulphite (Reimschneider,1963). It has an empirical formula of $\mathrm{C}_{9} \mathrm{H}_{6} \mathrm{O}_{3} \mathrm{Cl}_{6} \mathrm{~S}$ and a molecular weight of 406.97. The chemical structure is shown in Figure 1. Technical endosulfan, which is a light-brown solid, contains up to $96 \%$ endosulfan and is made up of the low-melting isomer (melting at $106^{\circ}-108^{\circ} \mathrm{C}$ ) and the high-melting isomer (melting at $208^{\circ}-210^{\circ} \mathrm{C}$ ) in the approximate ratio of $2: 1$ with a nelting range of $70^{\circ}-100^{\circ} \mathrm{C}$. The renaining $4 \%^{\circ}$ is made up of related 


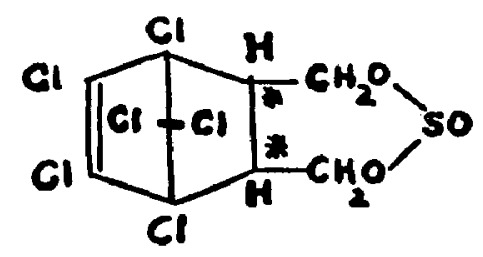

ENDOSULFAN

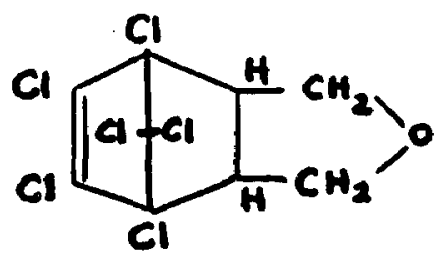

ENDOSULFAN ETHER

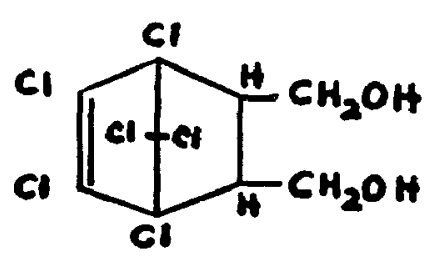

ENDOSULFAN ALCOHOL

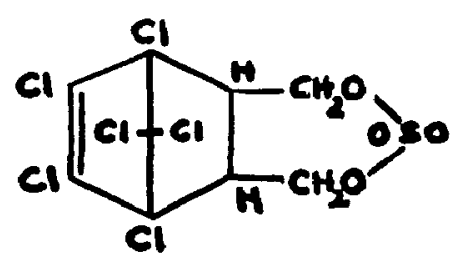

EMNDOSULFAN SULFATE

Figure 1. The structures of endosulfan and related chemicals. 
compounds and inert materials. Indosulfan is insoluble in vater but moderately soluble in most organic solvents. It has a density of 1.745 at $20^{\circ} \mathrm{C}$, and is sensitive to moisture, bases, and acids. It decomposes slowly by hydrolysis to endosulfan alcohol and $\mathrm{SO}_{2}$ (Dawsey,1964; Grahem t al. 1964; Kenaga, 1963, and Irartin 1961). Lindquist and Dahm (1957) used column and paper chromatography, ultraviolet and infrared spectroscopy to separate the isomers of endosulfan and its alcohol. In tests against female house flies, from a non-resistant strain, the estimated $L_{50}$ value was $6.7 \mathrm{ug} / \mathrm{g}$. The acute oral $L_{50}$ of purified technical grade endosulfan to male white rats was between 40 and $50 \mathrm{mg} / \mathrm{kg}$ of body weight. Zweig and Archer (1960) used gas chronatography for the quantitative deternination of endosulfan and its isomers in technical endosulfan and in enulsifiable concentrate formulations. Endosulfan extracts in benzene was eluted through a silicone chromosorb column, and its isomers was analyzed in quantities from 25 to 1000 ug with the Beclonan GC-2 and the filkins ierograph ModeI A-100. Terranova and Ware (1963) used gas chronatography and paper chromatography to determine endosulfan and related components in bean plants. Bames and Ware (1964) applied the techniques of gas chromatography, paper ohronatograyhy, and autoradiograms in studying the penetration and metabolism products of endosulfan in the house fly, llusca domestica I. 
An infrared speotrophotometric technique has bcen developed by Hooker Chemical Company for the assay of technical endosulfan. This method distinguishes between the isomers of endosulfan, can be used to determine the endosulfan alcohol and endosulfan ether impurities, and is precise to approxinately 2-3\% (Graham et al.1964).

Cassil (1958) and Graham (1959) describeà various colorimetric methods for determining endosulfan residues. Their procedures have been used as a general method for the control and routine testing of endosulfan dusts, wettable powders, and emulsifiable concentrates. In this method, which is a sulfite-iodometric procedure, endosulfan reacts with alkali to form an inorganic sulfite. This salt is then titrated with iodine and a starch indicator. The sulfite technique does not differentiate between the two endosulfan isomers since both respond to this method in the same way. Lndosulfan can be determined in the presence of endosulfan alcohol and endosulfan ether. thy compound that releases sulfur dioxide or other reducing substances upon treatnont with alkali interferes. Waitlen, Walker and westlake (1963) described an improved nethod wherein a pyridine-methanolic sodium hydroxide reagent was mixed with endosulfan extracts to develop a color, the density of which was proportional to the quantity of endosulfan and followed Beer's law. 
WLTERIAIS AND WETHODS

Lighty laboratory mice of the BiLB/cJarGnic strain, sibling mated for more than 90 generations, were used in this study. Fifty males and thirty females were rendomly selected from the healthy parents; the ages of these mice averuged about 90 days at the start of the experiments. Three to six mice of the same sex were usually housed in each care. The cages were stainless steel $12 \times 5 \frac{1}{4} \times 5$ inch. (Figure 2). Viater and food were given ad libitum. The cages were cleaned and cedar shavings litter changed weekly and the water changed twice a week. The food used throughout the experiment was Purina Laboratory House Chow. ${ }^{1}$ The animals were housed in an air-conditioned rearing roon temperatures ranging from $21^{\circ}-23^{\circ} \mathrm{C}$.

\section{Description of test compounds}

The Niarara Chemical Division, Food Hachinery and Chemical Corporation, ${ }^{2}$ furnished all of the endosulfan and related materials as well as the $\mathrm{C}^{14}$-endosulfan. The unlabeled materials wore purified endosulfan, technical endosulfan, endosulfan ether, endosulfan alcohol, low-neltine isomer (neltine at $106^{\circ}-108^{\circ} \mathrm{C}$ ), highrielting isomer (meltin $n_{6}$ at $208^{\circ}-210^{\circ} \mathrm{C}$ ), and endosulfan sulfate.

\footnotetext{
Ilianufactured by the Ralston Purina Co.,Checkerboard Square, st. Louis, irissouri.

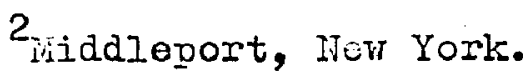




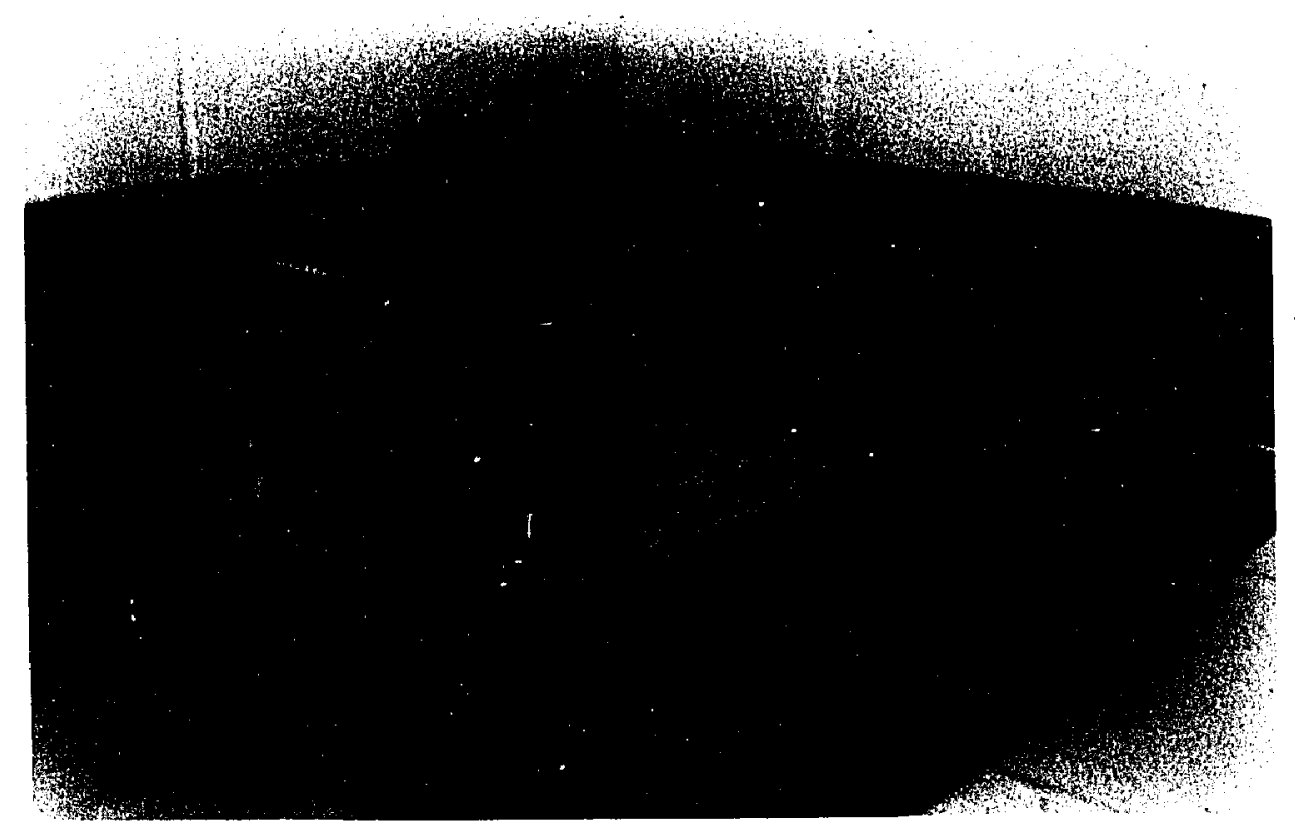

Figure 2. The stainless steel rearing case 
The $\mathrm{c}^{\mathrm{I}_{4}}$ endosulfan had a specific activity of $0.577 \mathrm{uc} / \mathrm{mg}$ and the $\mathrm{c}^{14}$-label was located in the hexachlorocyclodiene ring at carbons 5 and 6 (Figure 1 , see asterisks).

Standard solutions

The standard solutions of endosulfan isomers used in laboratory analyses were prepared by dissolving $10 \mathrm{mg}$ of the compound in $10 \mathrm{ml}$ of glass-distilled acetons. One milliliter of the original mixture was then mixed with $9 \mathrm{ml}$ of glass-distilled hexane. Dilutions were made until the final standard contained 0.1 nanogram ( $10^{-10}$ gram) in one microliter of the solution $(0.1 \mathrm{ng} / \mathrm{ul})$. These standard solutions were used in determining residues in the animal organs, by paper, thinlayer and gas chromatography. Fifty milligrams of $\mathrm{c}^{\text {llt }}$-endosulfan was dissolved in $10 \mathrm{ml}$ of glass-distilled acetone. One microliter of this solution then contained 5 ug of $0^{14}$-endosulfan.

Metabolism studies of unlabeled endosulfan

All mice used in the metabolism studies were fasted $12-18$ hours and weighed prior to feeding the treated and untreated food. These mice were then weighed again at the end of each study or prior to sacrifice. Organs or tissues such as liver, kidney, visceral fat, stomach, small intestine, muscle, brain, blood, heart, and spleen were weighed and placed in separate screw-cap vials which were stored in the freezer at $0^{\circ} \mathrm{C}$ until extracted. 
Five separate studies are involved. With normal or unlabeled endosulfan, mice were sacrificed 12 and 24 hours after a single dose and at weekly intervals during the feeding of $10 \mathrm{ppm}$ dietary endosul-

fan. Using $0^{14}$-endosulfan mice were sacrificed 24 hours after receiving a single dose, and after six daily doses.

Twelve-hour studies

Three adult males were used in this study. Two mice were given the endosulfan-treated mouse food at the concentration of $0.30 \mathrm{mg} / 300 \mathrm{mg}$ of food. A control mouse was given $300 \mathrm{mg}$ of food treated with 60 ul of acetone. To prepare the standard solution, $50 \mathrm{mg}$ of tho purified endosulfan was dissolved in $10 \mathrm{ml}$ of glass-distilled acetone, producing a concentration of $5 \mathrm{ug} / \mathrm{ul}$. Sixty microliters of the standard mixture were dropped on $300 \mathrm{mg}$ of food using a footmactivated microapplicator, ISco Model $\mathrm{N}^{3}$ (Figure 3), fitted with a \# 26 gauge needle. The microapplicator had been adjusted to deliver one microliter of liquid per signal.

After a mouse had eaten all the treated food, 15-30 mimutes, it was placed in the Roth metabolism cage (Roth et al.1948)(Figure 4 ). Untreated food was offered at intervals to these mice during the experimental period. Urine and fecal pellets were collected throughout the 12-hour period, and activities of each mouse were recorded until sacrificed. 


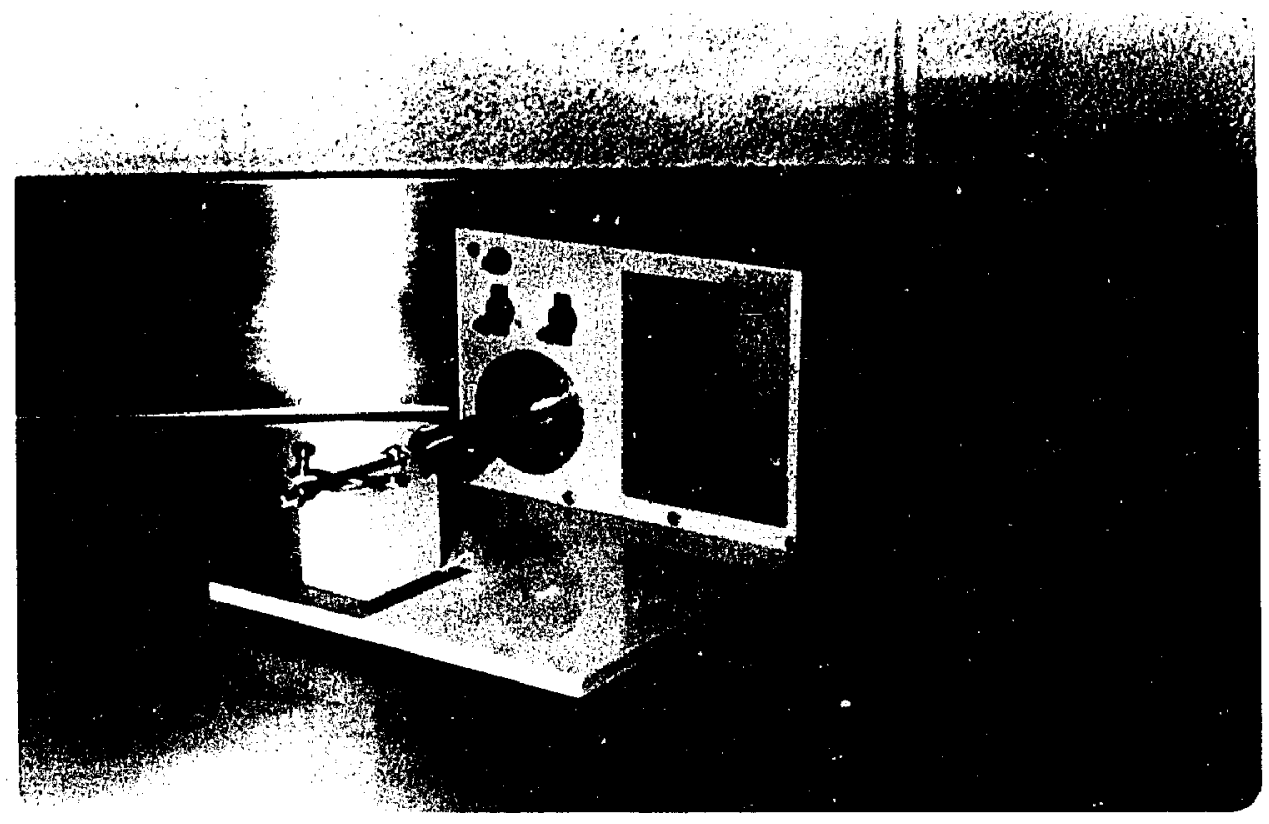

Fieure 3. The ISCO codel it microapplicator 


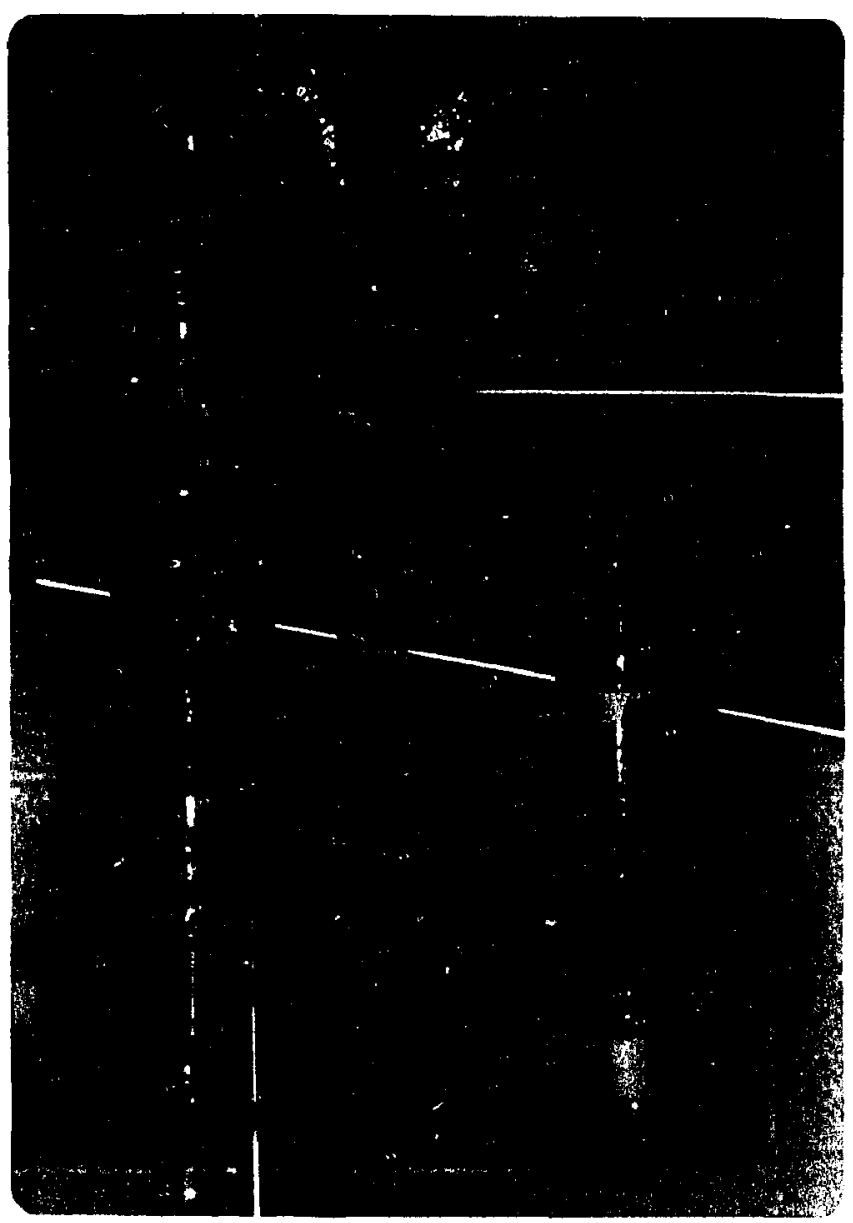

Figure 4. The Roth metabolism cage, modified to accomodate the laboratory mouse. 
Trenty four-hour studies

Purified endosulfan. - Ten adult males were used in this study. The microapplicator was used in preparing puritied endosulfan-treated food at $0.30 \mathrm{mg} / 300 \mathrm{mB}$ of food for each mouse. Nine mice were fed the tost diet and ono the control diet. After each mouse had consumed all the food, it was placod in the Roth metabolism cage. Untreated food was fed to them durine the experimental period. Urine and feces were collected throughout the 24-hour period, and activities of each mouse were recorded during the studies.

Low-nelting isomer.- Three adult malos were used in this study, two fed $0.30 \mathrm{mg}$ of low-melting isomer and one the control diet. The treated and control foods were prepared as in the yurified endosulfan exporiment except for the use of low-nelting isomer. Treatient and handing were the seme as just described. High-melting isomer.- Three adults nales were: used in this study, two for the $0.30 \mathrm{mg}$ of high-rielting isoner and one for the control diet. The treated and control foods were prepared as in the low-melting isomer experiment. Treatnent and handing were also the sane.

3. Iincoln, Nebraslca. 
Metabolism studies of purified endosulian

Ionser than 24 hours

Trenty mice, 10 males and 10 fenales, were used in this

study. Thoy waro held in the stainless steel cages, one mouse in each care. Wight of cach sex wore fed the food cointaining 10 pipn of the ourificd endosulfan and tro of bach sex were fed with the control food truated with the control food treated with acetone.

To propare the $10 \mathrm{ppm}$ vurificd cndosulfon dict, 6 kilograms of Purina Laboratory liouse Chow rere cround in a burr mill. The pulverizcd food was placed in an electric rotary mixer and $75 \mathrm{ml}$ of purified endosulfan solution was evenly and creadully distributed over it. The purified endosulfan solution was made from 60 mg of the purified endosulfan in $75 \mathrm{ml}$ of acetone. ifter the addition of $700 \mathrm{ml}$ of tap water, the nixture ras stirred 45 ninutes. The treated chow was then pelleted into $3 / 3$ inch diancter cylindrical pellets with a laboratory pellet mill4(piguro 5).

Thirty groms of 10 pipn purified endosulfon treated food rere given to cach mouse at the start of the exporiment. The trested and untreated foods were added whenover neccessury throughout the experinent. The amount of food consuncd by anch nouso per day was recorded until sucrificed. At the ond of $7,24,21,28,35,42$ and 49 days a male and a fenele on tho treated diet wore sacrificed. A mouso fed with acetono trcated food was sacrificed at the end of 14, 28,42 and 49 days.

4lianufactured by the Califormia Pellet rill co, Crawfordsville, Indiana. 
Tho mice were reighed at the beginning of the experiment and also before saarifice. Organs of the sacrificcd mouse were dissected, weighed, placed in the screw-cap vials and kept in the freezer at $0^{\circ} \mathrm{C}$ until extracted. 


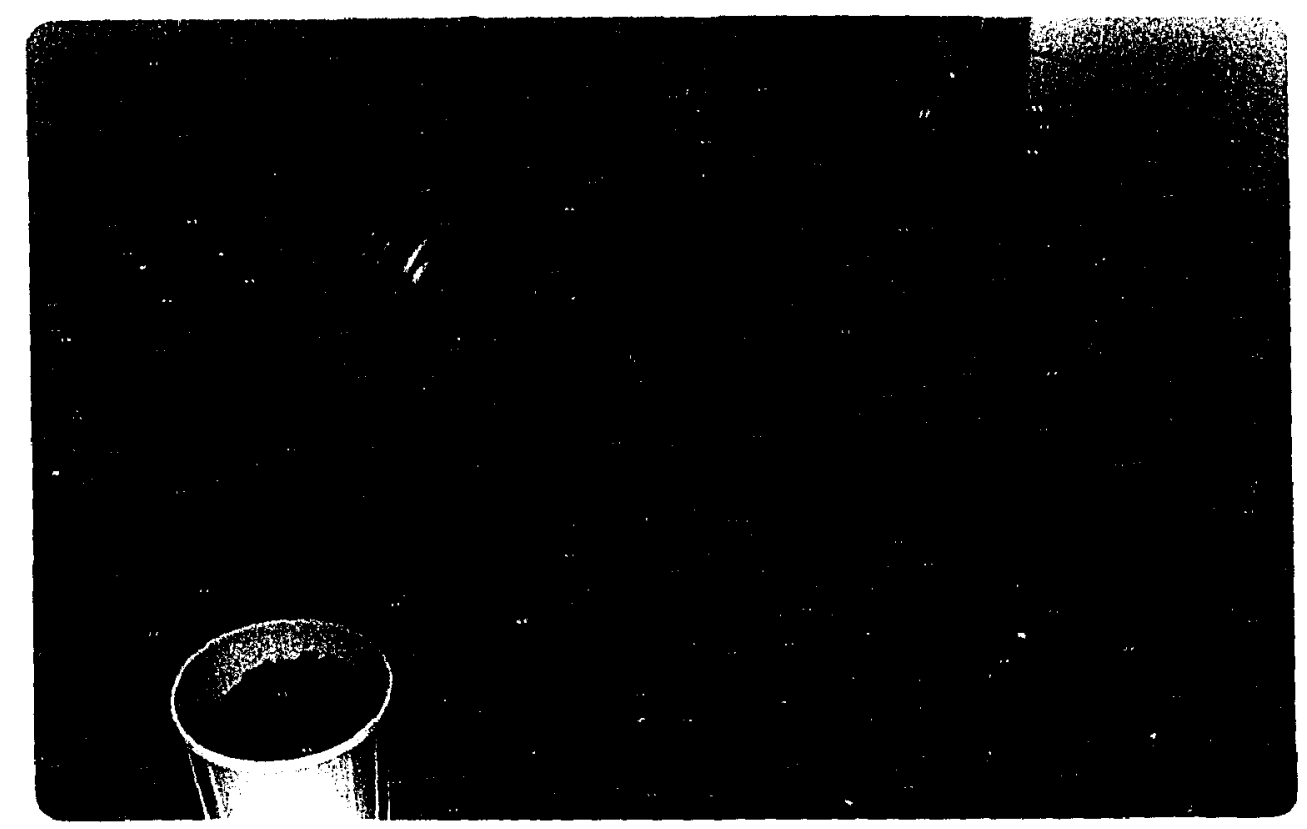

Figure 5. The laboratory pellet mill. 
Ixtraction proceduras of

unlabeled endosulfan

The organs as well as urine and feces, were removed from the freezer and allowed to reach room temperature prior to extraction. Each organ was diced with scissors and macerated with mortar and pestle in $5 x$ its weight of anhydrous sodium sulfate until powdered. The macerated organ was then extracted three times with a total of $25 \mathrm{ml}$ glass-distilled acetone and additional maceration (Taylor, Rea and Kirby,1964). The extracts were filtered through a dhatman $\# 1$ filter paper ${ }^{5}$ into a $40 \mathrm{ml}$ separatory funnel. Five milliliters of distilled water and ten milliliters of glass-distilled hexane were added to the filtrate, shaken well and allowed to stand for four minutes. The acetone portion was transfered into a second separatory funnel, and washed with ten milliliters of glass-distilled hexane, shaken well and allowed to stand for five minutes. The bottom portion wes discarded and the hexane rinses combined in the screwcap vial and dried in the hood. Five milliliters of glass-distilled hexane was added to the sample extract to dissolve the dried extracts prior to injection into the gas chromatograph. For the determination of endosulfan residues and the metabolism products of endosulfan in the animal organs and tissucs by paper or thinleyer chromatography, only $0.5 \mathrm{ml}$ of glass-distilled hexane was used for each sample spot. These extracts were again evaporated

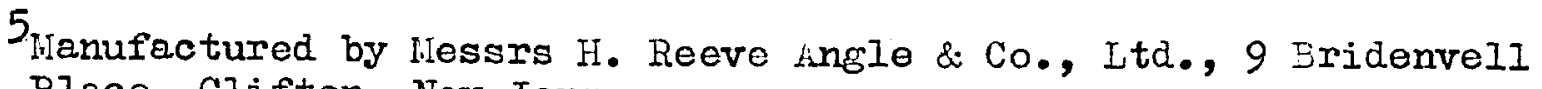
Place, Clifton, New Jersey. 
to dryness prior to returning to the frcezor. At a later date in this investigation, benzene, rather than hexane and acetone, was used in the fecal extractions. Feces and $5 x$ its weight of anhydrous sodium sulfate werc macerated in a contrifuge tube. The fecessodium sulfate was then extracted with 25 ml of benzene for approximately one hour, and the extract evaporated to five $m I$ in the hood. One microliter of the extract was injected into the gas chromatograph. The gas chronatographic results showed that in the benzene-extracted feces, oxidized endosulfan was detected. The results indicate that benzene is a suporior solvent for extracting feces of mice.

Ietabolisn studies of $\mathrm{C}^{14}$-endosulfan

The Roth metabolisn cage was desięned to collect urine,feces and respired air of an animal while it is metabolizing a radiocctive material, particularly one tagged with $\mathrm{C}^{14}$. If these metabolio products are collected at regular intervals, rates of detoxication, metabolic oxidation and other metabolic processes can be measured.

The apparatus which ras used is shown in Figure 6. A mouse was placed into the care on a galvanized steel hardware cloth floor. Fresh air, dried and freed of $\mathrm{CO}_{2}$ by passage tinrough Drierite ${ }^{6}(6 \mathrm{mesh})$ and Ascarite ${ }^{7}(8-20 \mathrm{mesh})$, was dram into the

\footnotetext{
6.ianufactured by Drierite Co., Kenia, Ohio.

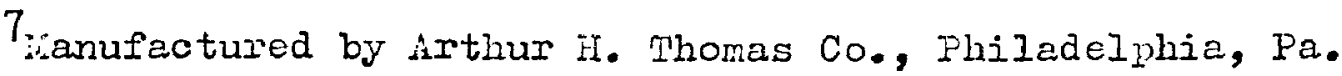


system through the opening tube at the top of the care at a rate of approximately $40 \mathrm{ml}$ per minute as measured by a flow meter. 8 The exhaled $\mathrm{CO}_{2}$ was collected in a train of five gas scrubbers containing $25 \mathrm{ml}$ each of $0.5 \mathrm{~N}$ iNaOH. Urine was collected in a vial and foces vere collected from the cage in a gless tube beneath the cage. Water was supplied through the top of the cage by a rater bottle. A single stick of mouse food $3 / 8 \times 1$ inch was provided through the feeding tube, which allowed the animal to eat without gnawing off any large particles and talking thom into the cage. In this study the air was drawn through the aninal chamber by a vacuum punp which caused a slight nesative pressure on the outlet side. In this way labeled carbon dioxido rould not bo lost should a small leak develop in the cage.

Six adult mice were used in this study, two meles and four females. Based on radioactivity measured by liquid scintillation of a standard collected at the time of food treatment, two were fed $0.30 \mathrm{mE}$, two fed $0.25 \mathrm{mg}$, and two fed $0.20 \mathrm{mg}$ of $\mathrm{c}^{14}$-endosulfan in $300 \mathrm{mg}$ of food. The microaplicator was used to apply the material as described above. A male was used as the control mouse and fed with the regular mouse food to which was added $40 \mu$ of acetone. One mouse was studied each time in the Roth metabolism cage during the 24 hours. Urine and feces were collected and removed at each excretion.

8 fanufactured by Fisher and Porter Co., Distributed by the Emil Greiner Co., 20-26 N. hoor Street, New Yorls 13, N.Y. 


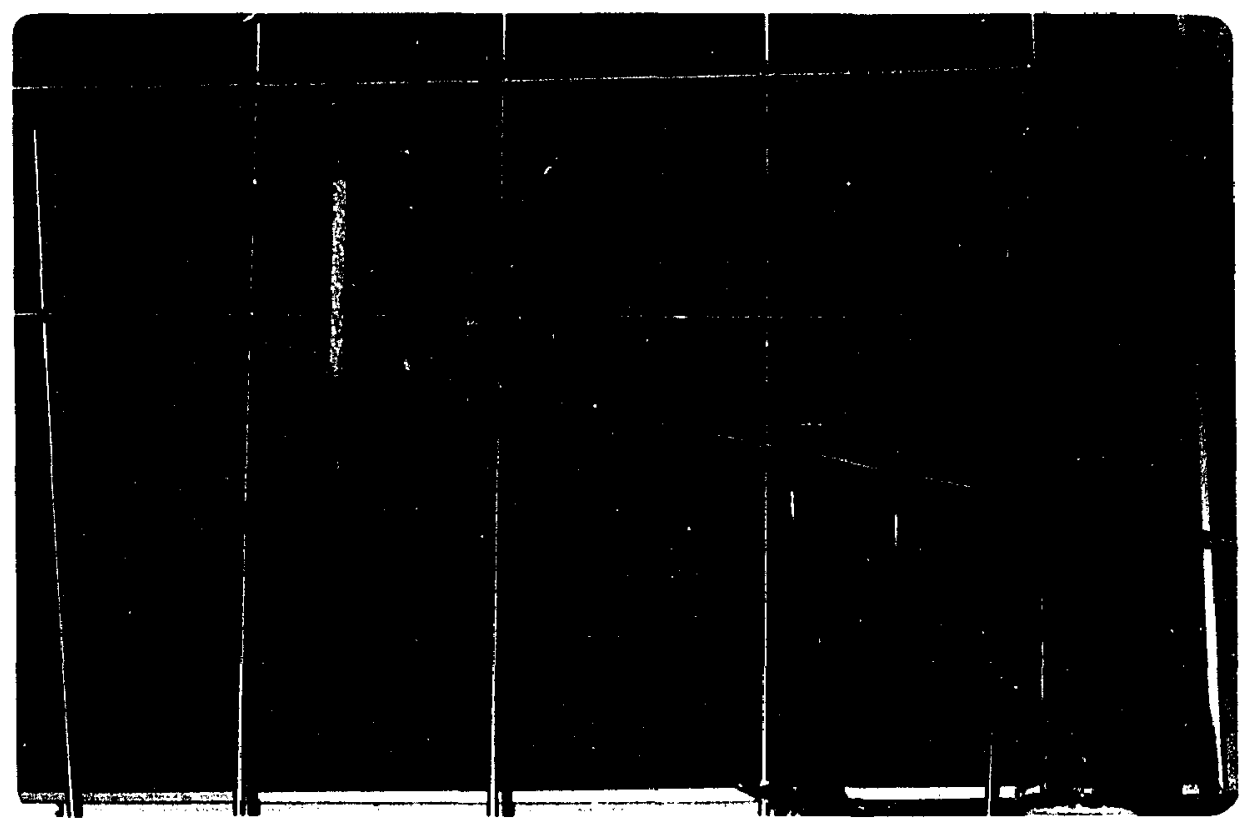

Figure 6. Apparatus used in the studies of $\mathrm{C}^{14}$ endosulfan metabolisn in the mouse. 
Extraction procedures

of $\mathrm{c}^{14}$-endosulfan

Urine samples were collected, measured, and diluted with $25 \mathrm{ml}$ glass-distilled acetone. The urine-acetone solution was then extracted with $20 \mathrm{ml}$ glass-distilled hexane after the addition of $5 \mathrm{ml}$ of distilled water. 'The extract was air-dried in the hood. Ten $\mathrm{ml}$ of a liquid scintillator ( $5 \mathrm{~g}$ of 2,5diphenyloxazole, PPO; $100 \mathrm{mg}$ of $2,2^{\prime}$ paraphenylene bis 5phenyloxazole, FOFOP; and $1000 \mathrm{ml}$ of toluene)(Hayes, 1963) was added and the vial shaken thorouchly to dissolve the residue. The activity was read with the liquid scintillation spectrometer (Figure 7). This instrument was a Packard liauid scintillation spectrometer, 9 iodel 3314, which had a 200 sample capacity, a belt-type sample chanfer, three channels, and an autonatic data lister. The data were collected from the red channel, the most appropriate for $\mathrm{C}^{14}$ and the gain sct at $8.5 \%$. The window was set at 50-1000 for the optinum ruading. The operatine tunpereture was $-6^{\circ} \mathrm{C}$. Prenty ml slass scror-cap counting vials ${ }^{9}$ were used. The reading tincs were 1,2 , and 10 ninutes for each sample. Since the baciceround was botween 16-18 counts Dor minute, all counting was standardized for 17 counts por mimto backeround.

9ianufactured by the Packard Instmuent Co., Inc., Dox 428 La Grange, III. 


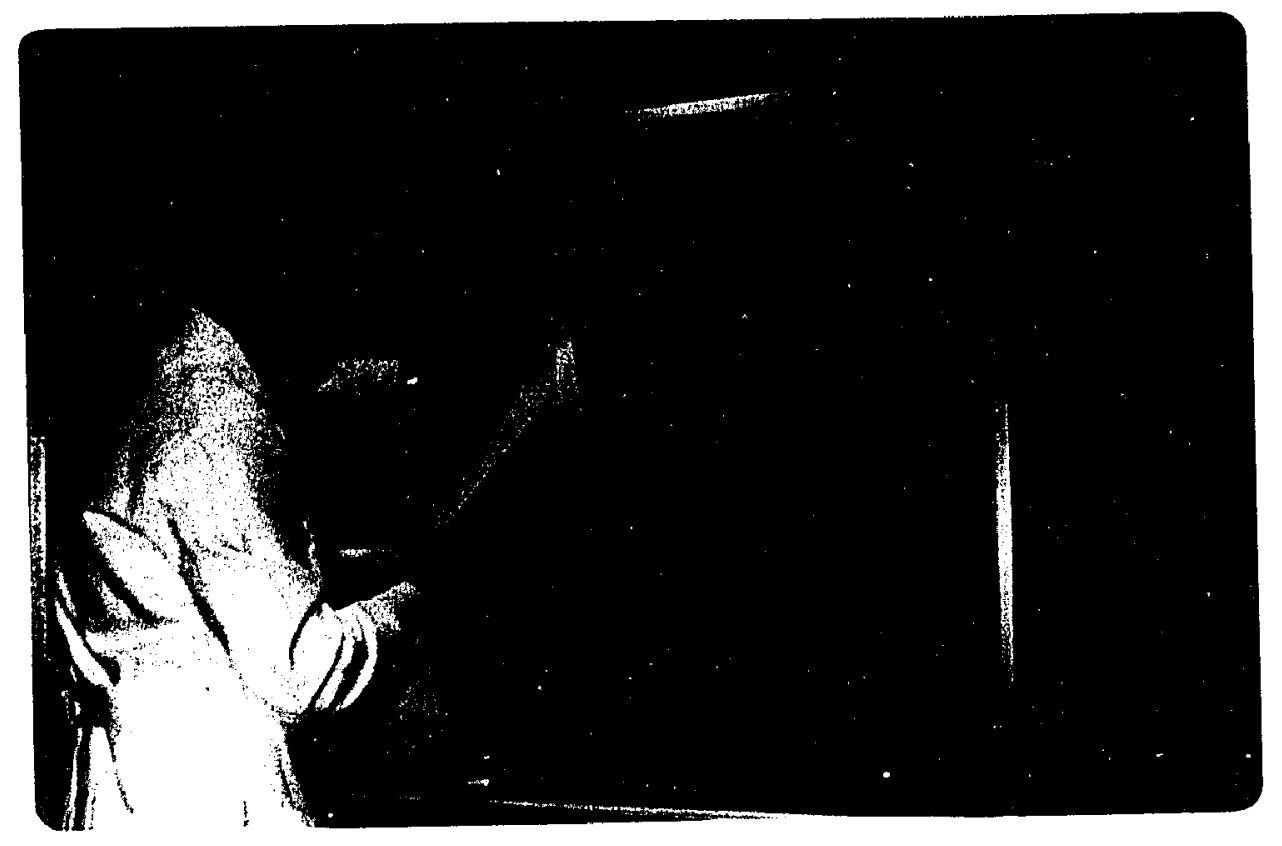

Figure 7. The tri-carb liquid scintillation spectrometer model 3314. 
Foces were ground with $5 x$ their weight of anhydrous sodium sulfate in a small mortar $23 / 4$ inches in diameter. The ground material was extracted three times totaling $25 \mathrm{ml}$ of slassdistilled acetone. The extracts were filtered through an $11 \mathrm{~cm}$ Whatrnan \# I filter paper into a $40 \mathrm{ml}$ separatory funnel. Pive $\mathrm{ml}$ of distilled water and $10 \mathrm{ml}$ of Elass-distilled hexane were added to the filtrates which were shalsen well and allowed to stand for four minutes. The actione portion was transferred to a second separatory funncl and extracted with $10 \mathrm{ml}$ of glass-distilled hexane, shaken and allowed to stand for fivo minutes. The hexane extracts were combined in $20 \mathrm{mI}$ screw-cap vials and dried in the hood as also were the acetone-water extracts and feces-sodium sulfate mixture.

Respired carbon dioxide was collected in $0.5 \mathrm{~N}$ WaOH and converted to $\mathrm{BaCO}_{3}$ by adding $10 \% \mathrm{BaCl}_{2}$ in excess. The $\mathrm{BaCO}_{3}$ was precipitated, filtered through a iillipor filter (which retained particles $0.45 \mu$ dianeter or larger ) and dricd in the oven at the temperature of $100^{\circ} \mathrm{C}$ for 5 hours. The activities of $0.25 \mathrm{gm}$, $0.5 \mathrm{gm}$ and $1.0 \mathrm{gm}$ sarples vero ncasured in the liquid scintillation spectrometer.

Tro fenale mice vere sacrificed after the 24-hour observation period. Iiver, kidney, brain, visceral fat, blood and small intestine vere extracted with acetone and hexane, by the same procedure given for feces. The hexane extracts, acctone-water 
extracts and the tissue-sodium sulfate portion were kept in the screw-cap vials and air dried. Ten $m$ l of the liouid scintillator described above was added to each vial, sholeen well and the activities were read with the liauid scintillation sjectrometer.

The carcass of the sacrificed nouso, less orcans, was weighed before and after the skin was lomoved. Hu sin was air-dried in the hood for 24 hours. The carcess was then diced with scissors and laccrated with 5 times its weicht of anhydrous sodiur sulfate in a 7 inches mortar until powdered and then weighed acain. Whree one gm samples of the carcass-sodiun sulfate rero used in readine the activities with the liquid scintillation syectrometer. The aried skin was also cut into sikell piecos with scissors and thon mized with the ronaning carcass-sodiun sulfute porder. The skin and carcass mixture was tinen divided into two perts and the $\mathrm{CO}_{2}$ extracted from each by moans of the Van Slykc procedure (Van Slyke and Folch, 1940; Van Slyke, Flazin and Heisiger 1.951). The rearents uscd vere based on the amounts of carbon in the animal tissues, which was estinated to be 60 percont of the dry weicht of the mouse. Seventy grams of dry reagents ( $\mathrm{ITO}_{3}+\mathrm{K}_{2} \mathrm{Cr}_{2} \mathrm{O}_{7}$ $10: 1 \mathrm{r} / \mathrm{ii}$ ) and $150 \mathrm{ml}$ of an acid nixture ( $1000 \mathrm{ml} \mathrm{Fi}_{3} \mathrm{PO}_{4}$, $1000 \mathrm{ml}$ $\mathrm{H}_{2} \mathrm{SO}_{4}$ and 30 gin $\left.\mathrm{KIO}_{3}\right)$ were used per gram of carbon in the dried tissue. The apparatus used for $\mathrm{C}^{14} \mathrm{O}_{2}$ production by Van Slyke procedure is shom in Pigure 8. 


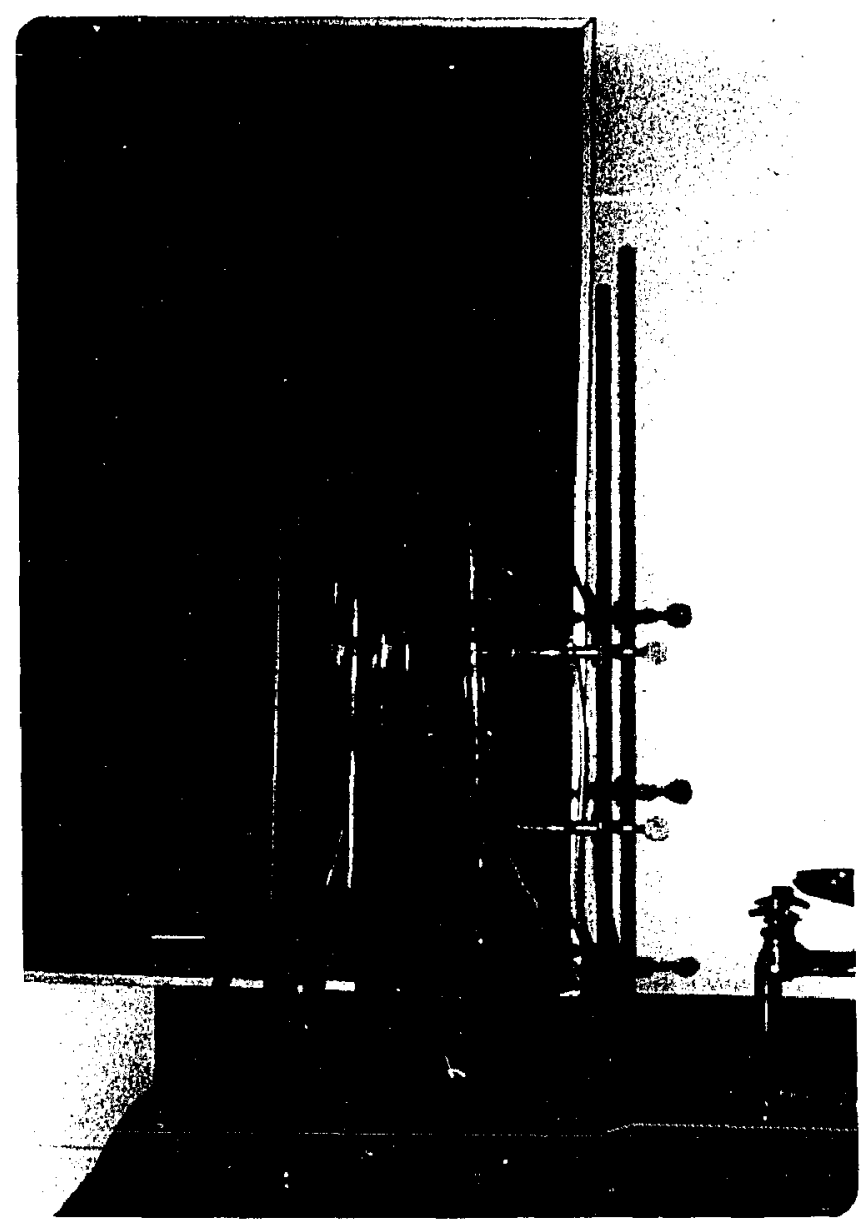

Figure 8. Apparatus for $\mathrm{C}^{14} \mathrm{O}_{2}$ production by Van Slyke procedure. 
The sample was heated.with an open flane and the $\mathrm{CO}_{2}$ produced by the reaction was passed through a stannous chloride tube to remove free iodine and was collected in a one liter glass tower filled with $900 \mathrm{ml} 2 \mathrm{~N}$ NeOK. A number of marbles were placed in the bottom of the tower and a Glass wool plue at tho top to increase absorption of $\mathrm{CO}_{2}$ by the NaOH. The combustion stopped after one hour of reaction and the systen was flushed with air for 5 minutes. The NaOr solution in the tower was then transferred to a $2000 \mathrm{ml}$ beaker, $400 \mathrm{ml}$ of $10 \% \mathrm{BaCl}_{2}$ were added and the mixture was stirred. The $\mathrm{BaCO}_{3}$ precipitated and was filtered through the Whatman \# 1 filter paper. The $\mathrm{BaCO}_{3}$ and the filter paper were dried in an oven at $100^{\circ} \mathrm{C}$ for 5 hours before the weight of $\mathrm{BaCO}_{3}$ was determined with an analytical balance. The dried $\mathrm{BaCO}_{3}$ was powdered with a 7 inches mortar and pestle and $0.25 \mathrm{gm}, 0.5 \mathrm{gm}$ and $1.0 \mathrm{gm}$ samples were placed in $20 \mathrm{ml}$ screw-cap vials. Ten $\mathrm{mI}$ of the liquid scintillator were added to the sample and the activities were read in the liquid scintillation spectrometer. The activity of the $\mathrm{C}^{14} \mathrm{O}_{2}$ produced by dicesting a pair of four grams carcas-sodium sulfate samples with the Van slyke reagents (Van Slyke et al. 1951) was read on a model 6000 Dynacon electrometer. ${ }^{10}$ A four gm sample was placed in the sample vial and 14 grams of dry reagent was added. The vial was lubricated with $\mathrm{H}_{3} \mathrm{PO}_{4}$ and then attached to the system. The ionization chember

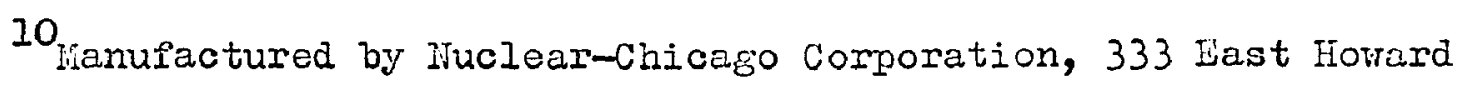
Ave. Des Plaines. IIl. 
was cvacuated through a by-pass and filled with $\mathrm{CO}_{2}$ through the by-pass two or threc times and then connocted to the Van slyke system. The by-pass then was filled up with $\mathrm{CO}_{2}$. The liquid Van Slyko reagent was added to the samplo vial (about $\frac{\lambda}{2}$ inch above tine lower surface of the entry tube) and the sample and the reagents were heated until the reaction stopped. ITomal $\mathrm{CO}_{2}$ ras then bubbled through the sample vial and all $\mathrm{CO}_{2}$ ontained Irom the reaction was ilushed into tho ionization chenver with the carrier gas (fillod to atmospheric pressure). All stopcocks were closed and the ionization chanber was removed and installed into the model 6000 Dynacon electroniter sjatem on which the activity of the simple was read in cineres. 'ihis value was compared with the value of a $\mathrm{CO}_{2}$ stendiud or with the stindardization chamber.

ietabolism studies of $\mathrm{c}^{14}$-endosulfan

Por Autoradiomams

Throc mice, trio malcs and one fiemale, wore used in this study. I male anci a remale wore each given 0.30 ing $c^{14}$-endosulfan on $300 \mathrm{mg}$ of food. $\therefore$ male control mouse was fed control food treated with $60 \mathrm{ml}$ Elass-distilled acetone on $300 \mathrm{mg}$ of food. Thasc nico were placod in the motabolism caocs. Tinine and focos were collected and activities of the nice wore rocorded tirroughout tho 24 hours. At the end of tho study tinoso mice vere sacrificed. and thuir organs artricted using the acutone-hezinc netrod. 
The extractions were dried in the hood and were kept in the freezer until paper chromatograms could be developed from which autoradiograms were made.

Metabolism studies of $\mathrm{c}^{14}$-endosulfan

longer than 24 hours

Ten mice, eight rales and two females, were used in the studies. One male and a female were used for the control animals. The treated mice were fed with $0.1 \mathrm{mg}^{1} \mathrm{C}^{14}$-endosulfen twice daily for several days. These nice were sacrificed at intervals and the activities and location of radioactive materials were determined by using the autoradiogram technique.

\section{Paper chronatography}

Ascending, reversed phase paper chromatorraphy was used to identify the residues of endosulfen and its metabolism products in nouse organ and tissue extricts. The methods used were based on those of lifitchell (1958) and Terranova and Ware (1963).

A sheot of Whatran \# 1 , filter paper, ${ }^{5} 18 \frac{1}{4} \times 22 \frac{1}{2}$ inches, was cut to make four sheets $8 \times 10$ inches. The papers vere cut in a manner that when developed the mobile solvent would move in the sare direction as the grain of paper. A line $3 / 4$ inch from the bottom of the paper was then drawn the width of the sheet with a srephite pencil. This line was marked at nine points 
3/4 inch apart ending one inch from either side of the paper. The scraps were used to make strips $I \times 8$ inches which were folded lengthwise, placed over the top of the $8 \times 10$ inches sheet and stapled so that a $1 / 8$ inch glass rod could bo inserted in the fold to support the paper. Tach sheet was washed 12 times with distilled water and glass-distilled acctone alternately and hung to dry at least 24 hours. The dried paper was then sprayed on both sides with a total of $50 \mathrm{ml}$ of diethy ether in which was dissolved $4 \%$ USF medium grude mineral oil (V/V) and dried for at least 24 hours prior to spotting with extracts. A 10 ul Harilton micro-syringe ${ }^{11}$ was modified for the spottings by cutting the pointed tip of the needle off and then bendins the needle to a $90^{\circ}$ angle. The standard solution and the extracts were dried with warm air from a hair dryer after each spotting to keep the spot small prior to the next spotting. Each spot was identified with a pencil mark. Up to six chronatograms were then put in the chromatographic developine tank, $9 \times 12 \times 13$ inches hard rubber, which had been lined with filter papers. The chromatographic tank was then closed and sealed with masking tape.

Fifty ml of the mobile solvent, $65 \%$ glass-distilled methylcellusolve and 35\% distilled water, were placed in the trough through a side opening and allowed to equilibrate for 2 hours before adding more mobile solvent to raise the level $\frac{1}{2}$ inch above

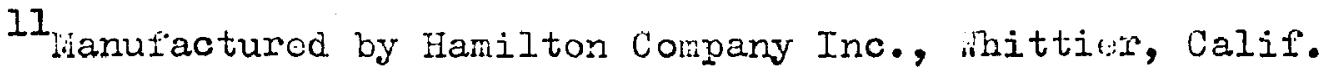


The lower edge of the suspended chromatorrams. The chromatogrins were developed in the tank for at lesst six hours or until the mobile front reached a point one inch from the top. The chromatograms were removed irom the tank, the front marked with a Graphite poncil and hung to dry at room temperature. They were then sprayed with a chromorenic afent or exposed to kodak iro-screen jiedical ( $8 \times 10$ inches) $x$-ray film. ${ }^{12}$ The chromogenic agent used was based on the method of hitchell (1958), which contained $0.85 \mathrm{gm} \mathrm{AgNO}_{3}$ dissolved in $2 \mathrm{ml}$ of distilled water and $10 \mathrm{ml}$ 2-phenoxy ethanol diluted to $200 \mathrm{ml}$ with glass-distilled acetone. Both sides of the chromatogram were sprayed with $40 \mathrm{ml}$ of the chromogenic agent, $20 \mathrm{ml}$ per side. The sprayed chromatogram was air-dried priol to placing under three, 30 watt, ultraviolet lamps ${ }^{13}$ mounted in a specially built case six inches above the chromatograms, for 20 minutes or until the spots appeared. The spots were circled with a graphite pencil and then the chromatograms were washed twice with distilled water and air-dried.

$R_{f}$ values were determined for the standard isomers of endosulfan and for technical endosulfan. These values were used as the basis for determining the results of the residues and metabolism studies.

\footnotetext{
12 Hanufactured by Eastman Kodak Co., Kochester 4, Now York. 13 ilanufactured by the General Ulectric Co.,Cleveland, Ohio
} 


\section{Gas chromatography}

A Barber Colman irodel 15 gas chromatograph $^{14}$ was used for analysis of all endosulfan extracts. The chromatograph was equipped with an electron capture detector which utilized either radium 226 or tritium. The recorder, a single point series 8000 with $1 / 3$ inch per minute chart speed, was used for recording the results from all extracts. The column used in this study ras a 4-foot, $1 / 8$ inch inside diameter, U-shaped, Fyrex glass column. The column was pecked with $1.5 \%$ SE 52 silicone gum muber coated on 60/80 mesh Gaschrom ${ }^{15}$ solid support. The anode voltages used in this study varied between $35-37.5$ volts except where indicated. Throughout the experiment the temperatures of operation were the column at $205^{\circ} \mathrm{C}$, the detector at $220^{\circ} \mathrm{C}$, and the injection block at $250^{\circ} \mathrm{C}$. The sensitivity of the machine was set either at 10 or 30 , with an attenuation of one. A molecular seive column connected the gas chromatograph and the tank of Hy-pure Nitrogen gas. 16 The nitrogen flow measured on the effluent side of the detector was $100 \mathrm{ml} / \mathrm{min}$ with no scavenger flow.

A 10 Ml Hamilton micro-syrinfo was used to inject the extracts and the stendard mixtures. The amount of the sarnple

\footnotetext{
14 iranufactured by the Barbor-Colman Co., Hockford, Illinois.

15 ilanufactured by Ápplieà Science Laboratory, $140 \mathrm{~N}$. Barnard Street, State College, Pennsylvania.

16. Wanufactured by Iiquid Carbonics Division of General Dynamics.
} 
injected each time was carefully measured and controlled as described by Barnes and Ware (1964, in press). The injections were made twice for each extraction with $2 \mu l$ or more for each injection. To identify an unknown peak from the animal extracts, the standard mixture and the unknown sample were combined and injected together. The standard mixtures were injected alternately with the animal extracts to check the sensitivity of the detector throughout the period of injection.

\section{Thin-layer chromatosraphy}

Thin-layer chromatography on silica gel ${ }^{17}$ was used for the determination of endosulfan residues and endosulfan metabolites in the mouse organs, urine and feces. Walker and Beroza (1963) discussed the use of the thin-layer chromatography as a method for the cleanup of insecticides and 19 testing dyes. Kovacs (1963) also used thin-layer chromatography to detect chlorinated pesticide residues in various food products. He stated that thin-layer chromatography techniques could detect chlorinated pesticide residues as low as 1 part per billion. Horley and Chiba (1964) demonstrated the use of thin-layer chromatography for dotecting chlorinatod pesticide residues without cleanup.

The equipment used was a fixed thickness applicator, 18 the chromatographic tank, plate holder, drying rack and

\footnotetext{
17 Hanufactured by E. Herck, Darmstadt, West Germany.

18 iianufactured by the Research Specialties Co., 200 South Garrard Blve., Richmond, Calif.
} 
$8 \times 8$ inches glass plates. To coat 5 plates, $30 \mathrm{~g}$ oi silica gel and $55 \mathrm{ml}$ distilled water were mixed together. The plates were dried in position on the mounting board for $20-25$ minutes and then dried in the oven for 30 minutes at $75^{\circ} \mathrm{C}$. The plates were prewashed twice with distilled water ( Kovaca,1963) prior to spotting with the extracts. To apply the extracts on the plate, a pencil maxk was made $1 \frac{1}{2}$ inches from the bottom edge of the plate on both sides. An imaginary line between the two points indicated the sample spotting or origin line. A line was drawn, which removed the coating, completely across the plate $5 \frac{1}{2}$ inches from the bottom edge, to represent the solvent front after development. On the lower edge of the adsorbent, starting $3 / 4$ inch from the left edge of the plate, 9 marks were made with a pencil at $3 / 4$ inch intervals, to serve as horizontal guides for sample application. The identities of the samples were etched above the solvent front. The sample was repeatedly transferred with the microsyringe to one of the origin points on the plate, dried after each application to restric spot size. Standard solutions of endosulfan were transferred to other spots on the same plate with the microsyringe. The chromatographic tank was cleaned and dried before using. The nobile solvent used was $4 \%$ redistilled acetone in $n$-heptan $\theta^{19}(\mathrm{~V} / \mathrm{V})$. when the solvont front just reached the pencil line $10 \mathrm{~cm}$ above the spotting line, the plates were removed and allowed to air-dry in the hood for 19. 
five minutes. The plates were then sprayed with the chromogenic agent, prepared with 1.7 gm $\mathrm{AgIO}_{3}$ dissolved in $2 \mathrm{nl}$ of distilled water and $10 \mathrm{ml} 2-$ phenoxy ethanol diluted to $200 \mathrm{ml}$ with glassdistilled acetone, using lateral motions of the spray bottle parallel to the direction of solvent flow. After spraying, the plates were dried in the hood for five minutes, then in a forced draft oven at $75^{\circ} \mathrm{C}$ for 15 minutes. The plates were renoved from the oven and cooled then exposed to the ultraviolet lamps until the spot for the standard of the lowest concentration appeared.

\section{Autoradiography}

Autoradiography is concerned principally with the location of the radioactive atoms. Basioally, the autoradiographic technique consists of placing a radioactive specimen in contact with a photographic enulsion. The radiation, passing through the film, sensitizes the silver grains which upon development will show the location of radioactive atoms in the specimen.

The paper chromatograns which were spotted with extracts from orfens, urine and feces of the mice red $\mathrm{C}^{14}$-endosulfan were developed in the usual manner as nonlabeled endosulfan. After 6-7 hours of developing in the chromatographic tank, they were renoved, air-dried and then placed under the Kodak No-screen Nedical $\mathrm{X}$-ray film $(8 \times 10$ inches $)$ in Kodale casettes in the darleroom. They were left in the casette for at least 25 days 
before developing in DK-50 developer 20 for five minutes, fixed for 15 minutes and washed in $20^{\circ}-21^{\circ} \mathrm{C}$ running tap water for two hours. The developed X-ray film was then air-dried and the spots were identified by comparing with the chromogenically produced spots of the paper chromatogram.

20 Hanufactured by Eastman Kodak Co., Rochester 4, Wer York. 


\section{RESULTS RID DISCUSSIOH}

Paper chromatographic analyses of both the purified endosulfan and its isomers are shown in Figure 9. The purified endosulfan produced two spots whose $\mathrm{h}_{f}$ values corresponded to those of the low- and high-melting isomers. The $R_{f}$ values of the isomers of endosulfan are summarized in Table 1. A gas chromatographic analysis of all components and the endosulfan sulfate standards are prescnted in Figure 10. 

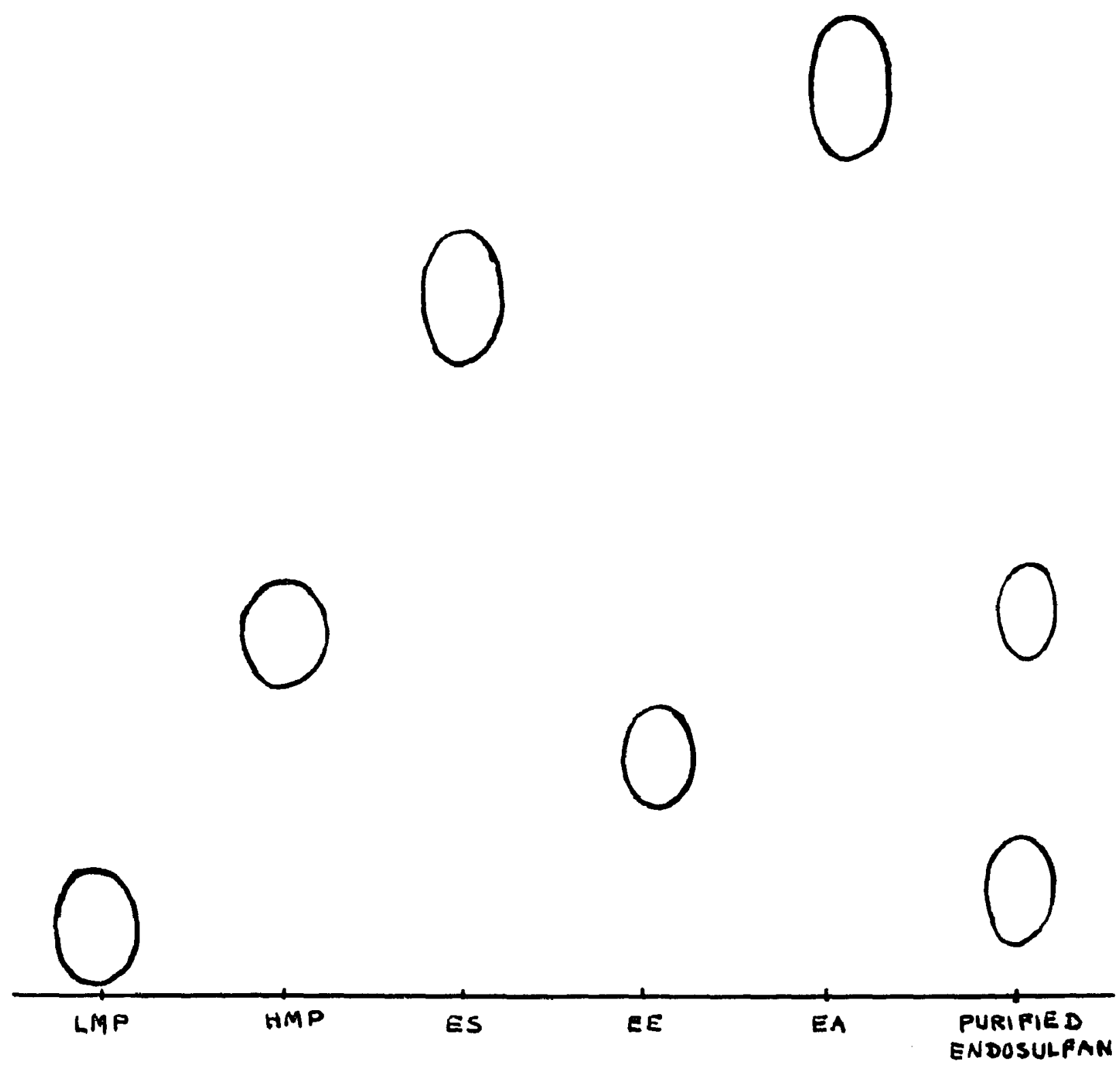

Figure 9. Paper chromatograph trace of 5 ug quantities of endosulfan standards. Six-hour development at $24-25^{\circ} \mathrm{C}$. lobile phase, 65\% methyl cellosolve in water. Stationary phase, 4\% mineral oil in diethyl ether. 
Table 1. - $R_{f}$ values of technical endosulfan and related derivatives using reverse phase asconding paper chromatography.

\begin{tabular}{lc}
\hline Standard & $R_{f}^{*}$ \\
\hline Endosulfan Lotilelting Point isoner (LIP) & $0.11,0.06,0.06$ \\
Endosulfan High-irelting Point isoner (ILIP) & $0.33,0.26,0.29$ \\
Endosulfan Ether (EE) & $0.23,0.26,0.29$ \\
Endosulfan Sulfate (ES) & $0.67,0.75,0.76$ \\
Endosulfan Alcohol (Ei) & $0.84,0.83$ \\
\end{tabular}

* Hobile phase, $65 \%$ methyl cellosolve in rater. Stationary phese, $4 \%$ mineral oil in diethyl ether. 


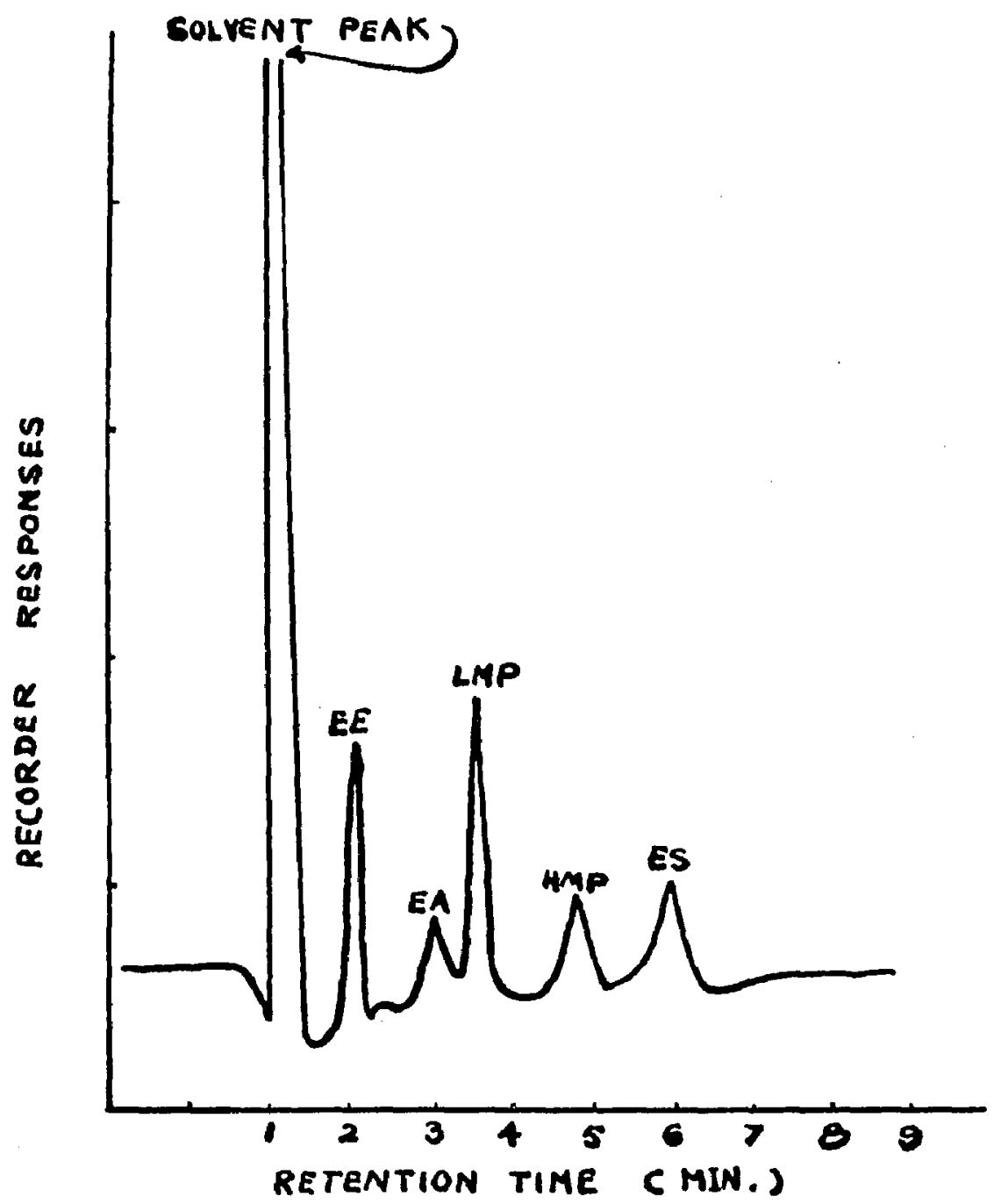

Figure 10. Gas chromatogram of endosulfan isomers and related produots.

Detector : Tritium

Injection temperature: $225^{\circ} \mathrm{C}$

Column temperature : $210^{\circ} \mathrm{C}$

Deteotor temperature: $222^{\circ} \mathrm{C}$ 
Results of the metabolic studies by using $C^{14}$-endosulfan in mice are summarized in Tables 2 and 3. Two adult mice were sacrificed at the end of each experiment. The radioactivity of organs, urine, feces, a nd the expired gas of one of the mice were read with the liquid scintillation spectrometer and the Hodel 6000 Dynacon electrometer which is shown in Table 2. Only the Iiquid scintillation spectrometer was used in reading the radioactivity of the other test mouse (shown in Table 3). By using the Fodel 6000 Dynacon electrometer and liquid scintillation spectrometer, the percent recovery was greater (65.7\%) than when the liquid scintillation spectroneter was used alone (21\%). This may be due to the settling of $\mathrm{BaCO}_{3}$ to the bottom of the vial or a mechanical quenchine by the $\mathrm{BaCO}_{3}$. The author found that by shaking the vial vigorously prior to reading in the liquid scintillation spectrometer, the radioactivity was highest and then decreased rapidiy with time. it the end of ten minutes the activity decreased avout $33 \%$ compared with the first readine (Figure 1I). Color in organ, urine and focal extracts nay have caused some quenching in the systen which in turn reduced the midioactivity read by the spectrometer. In using the liodel 6000 Dynacon electrometer, the problen of quencining and settling e frect wore erased because the syston produced $\mathrm{C}^{14} \mathrm{O}_{2}$ was readily read with the electrometer. If the Hodel 6000 Dynacon had been usod in reading the radioactivity from the second nouse along 
with the liquid scintillation spectrometer, the percentage of recovery should have been identical to the first test nouse. Based on two mice, the amounts of ridioactivity found from these experiments were in the following secuence: Fecos) siall intestine and contents > urine) visceral fat) liver) kidney) resiratory $\mathrm{CO}_{2}$ > blood. From 0.1 to 0.2 percent of tho radioactivity was found in the exhalcd gas indicatine that the aninal con motabolize the cyclo diene rine and ultimately convort the products to $\mathrm{CO}_{2}$.

Based on the specific activity (activity/ veight) of the organs and excreta the following soquence was obtained: Feces $98452 \mathrm{cpm})\rangle$ visceral fat $(7053.5 \mathrm{cpm})$ ) urine $(3746 \mathrm{cpm})>$ Iiver (2883 cpm) ) sriall intestine and contents (2080 cpra) $)$ Hidney (1390 cpm)) Brain (424.6 cpm)) respiratory $\left.\mathrm{CO}_{2}(302 \mathrm{cpm})\right) \mathrm{blood}$ $(92.3 \mathrm{cpm})$. 
Table 2.- Radiocictivity found in organ extracts, fespired $\mathrm{CO}_{2}$, urine and feces 24 hours following oral dose of $\mathrm{C}^{14}$-endosulfan in a mouse. The radioactivity were measured with a Tri-Carb Iiquid scintillation model 3314 and a model 6000 Dynacon electrometer.

\begin{tabular}{|c|c|c|c|c|}
\hline Source & $\begin{array}{l}\text { ixtract } \\
\text { fraction }\end{array}$ & $\begin{array}{l}\text { CPIi less } \\
\text { bacikground }\end{array}$ & $\begin{array}{l}\text { Total } \\
\text { CPI-j }\end{array}$ & $\begin{array}{l}\% \text { of recovered } \\
\text { radioactivity }\end{array}$ \\
\hline Liver & $\begin{array}{l}\text { Hexane } \\
\text { Acetone: } \mathrm{H}_{2} \mathrm{O} \\
\mathrm{Na}_{2} \mathrm{SO}_{4}: \text { tissue }\end{array}$ & $\begin{array}{r}1538.0 \\
1439.0 \\
470.0\end{array}$ & 3447.0 & 2.12 \\
\hline Kidney & $\begin{array}{l}\text { Hexane } \\
\text { icetone: } \mathrm{H}_{2} \mathrm{O} \\
\mathrm{Na}_{2} \mathrm{SO}_{4}: \text { tissue }\end{array}$ & $\begin{array}{r}120.5 \\
39.3 \\
271.6\end{array}$ & 431.4 & 0.27 \\
\hline $\begin{array}{l}\text { Small } \\
\text { Intestine }\end{array}$ & $\begin{array}{l}\text { Hexane } \\
\text { Acetone: } \mathrm{H}_{2} \mathrm{O} \\
\mathrm{Ia}_{2} \mathrm{SO}_{4}: \text { tissue }\end{array}$ & $\begin{array}{l}434.2 \\
205.9 \\
276.0\end{array}$ & 916.1 & 0.58 \\
\hline Erain & $\begin{array}{l}\text { Hexane } \\
\text { Acetone: } \mathrm{H}_{2} \mathrm{O} \\
\mathrm{Na}_{2} \mathrm{SO}_{4}: \text { tissue }\end{array}$ & $\begin{array}{l}68.0 \\
25.2 \\
72.0\end{array}$ & 165.2 & 0.104 \\
\hline $\begin{array}{l}\text { Viscoral } \\
\text { fat }\end{array}$ & $\begin{array}{l}\text { Hexane } \\
\text { icetone: } \mathrm{H}_{2} \mathrm{O} \\
\mathrm{Iva}_{2} \mathrm{SO}_{4}: \text { tissue }\end{array}$ & $\begin{array}{r}1825.0 \\
0.0 \\
189.0\end{array}$ & 2014.0 & 1.27 \\
\hline Blood & $\begin{array}{l}\text { Hexane } \\
\text { Acetone: } \mathrm{H}_{2} \mathrm{O} \\
\mathrm{Na}_{2} \mathrm{SO}_{4}: \text { tissue }\end{array}$ & $\begin{array}{l}30.0 \\
34.3 \\
28.0\end{array}$ & 92.3 & 0.06 \\
\hline Urine 抽 1 & $\begin{array}{l}\text { Hexane } \\
\text { Acetone: } \mathrm{H}_{2} \mathrm{O}\end{array}$ & $\begin{array}{l}237.6 \\
386.0\end{array}$ & 623.6 & 0.40 \\
\hline Urine $\frac{71}{\pi} 2$ & $\begin{array}{l}\text { Hexane } \\
\text { Acetone: } \mathrm{H}_{2} \mathrm{O}\end{array}$ & $\begin{array}{r}76 \cdot 7 \\
352 \cdot 3\end{array}$ & 429.0 & 0.27 \\
\hline Urine it 3 & $\begin{array}{l}\text { Iiexane } \\
\text { Acetone: } \mathrm{H}_{2} \mathrm{O}\end{array}$ & $\begin{array}{l}210.0 \\
347.0\end{array}$ & 1057.0 & 0.67 \\
\hline Feces $\frac{17}{\pi t} 1$ & $\begin{array}{l}\text { Hoxane } \\
\text { icetone: } \mathrm{H}_{2} \mathrm{O} \\
\mathrm{ITa}_{2} \mathrm{SO}_{4}: \text { Poces }\end{array}$ & $\begin{array}{r}69.8 \\
5.3 \\
49 \cdot 0\end{array}$ & 124.1 & 0.078 \\
\hline
\end{tabular}


Table 2. (Conta.)

\begin{tabular}{|c|c|c|c|c|}
\hline Source & $\begin{array}{l}\text { Ixtract } \\
\text { fraction }\end{array}$ & $\begin{array}{l}\text { CPIf less } \\
\text { bacliground }\end{array}$ & $\begin{array}{l}\text { Total } \\
\text { CPI }\end{array}$ & $\begin{array}{l}\% \text { of recovered } \\
\text { radioactivity }\end{array}$ \\
\hline Feces 位 2 & $\begin{array}{l}\text { Hexane } \\
\text { Acetone: } \mathrm{HH}_{2} \mathrm{O} \\
\mathrm{Na}_{2} \mathrm{SO}_{4}: \mathrm{feces}\end{array}$ & $\begin{array}{r}153.0 \\
61.0 \\
1103.0\end{array}$ & 1317.0 & 0.83 \\
\hline Feces \# 3 & $\begin{array}{l}\text { Hexane } \\
\text { Acetone: } \mathrm{H}_{2} \mathrm{O} \\
\mathrm{Ia}_{2} \mathrm{SO}_{4}: \mathrm{feces}\end{array}$ & $\begin{array}{r}729.0 \\
464.0 \\
2489.0\end{array}$ & 3682.0 & 2.33 \\
\hline Feces \# 4 & $\begin{array}{l}\text { Hexane } \\
\text { Acetone: } \mathrm{H}_{2} \mathrm{O} \\
\mathrm{Na}_{2} \mathrm{SO}_{4}: \text { feces }\end{array}$ & $\begin{array}{r}722.0 \\
243.0 \\
4277.0\end{array}$ & 5242.0 & $3 \cdot 32$ \\
\hline $\begin{array}{l}\text { Contents in } \\
\text { Gastrointes- } \\
\text { tinal tract }\end{array}$ & $\begin{array}{l}\text { Hexane } \\
\text { Acetone: } \mathrm{H}_{2} \mathrm{O} \\
\mathrm{lia}_{2} \mathrm{SO}_{4}: \text { contents }\end{array}$ & $\begin{array}{r}105.0 \\
2205.0 \\
54.0\end{array}$ & 2364.0 & 1.50 \\
\hline $\begin{array}{l}\text { Respiratory } \\
\qquad \mathrm{CO}_{2}\end{array}$ & $\mathrm{BaCO}_{3}$ & 207.0 & 207.0 & 0.13 \\
\hline Carcass & $\mathrm{BaCO}_{3}$ & $30795.0^{*}$ & 130795.0 & 82.93 \\
\hline ECuipment & & 4800.0 & 4800.0 & 3.10 \\
\hline Total & & & 158706.7 & \\
\hline $\mathrm{c}^{14}$-endosulte & an standard & & 240000.0 & \\
\hline
\end{tabular}

Percent recovered $=65.7 \%$ * Eauivalent CPi Pron $\mathrm{C}^{14} \mathrm{O}_{2}$ actj.vity neasured with the Dynacon
6000 electroneter. 
Table 3. - Radioactivity found in orson cxtracts, fgspired $\mathrm{CO}_{2}$, urine and feces 24 hours folloring oral dose of $\mathrm{C}^{\text {l4 }}$-endosulfan in a mouse. The radioactivity verc measured with a Tri-Carb liquid scintillation model 3314.

\begin{tabular}{|c|c|c|c|c|}
\hline Source & $\begin{array}{l}\text { Extract } \\
\text { fraction }\end{array}$ & $\begin{array}{l}\text { CPif less } \\
\text { bacliground }\end{array}$ & $\begin{array}{c}\text { Total } \\
\text { CPi: }\end{array}$ & $\begin{array}{l}\text { of recovered } \\
\text { radioactivity }\end{array}$ \\
\hline Iiver & $\begin{array}{l}\text { Hexane } \\
\text { Acetone: Hi } \\
\mathrm{Ha}_{2} \mathrm{SO}_{4}: \text { tissue }\end{array}$ & $\begin{array}{l}623.0 \\
.1164 .0 \\
2003.22\end{array}$ & 3790.22 & 1.33 \\
\hline lidney & $\begin{array}{l}\text { Hexane } \\
\text { icetono: } \mathrm{H}_{2} \mathrm{O} \\
\mathrm{Ma}_{2} \mathrm{SO}_{4}: \text { tis sue }\end{array}$ & $\begin{array}{r}70.0 \\
54.0 \\
237.0\end{array}$ & 361.00 & 0.98 \\
\hline $\begin{array}{l}\text { Small } \\
\text { Intestine }\end{array}$ & 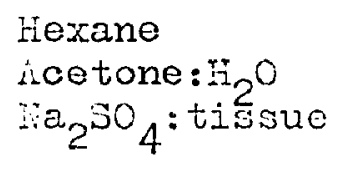 & $\begin{array}{c}205.0 \\
376.0 \\
1483.70\end{array}$ & $2064 \cdot 70$ & 5.62 \\
\hline Stonich & $\begin{array}{l}\text { rcxane } \\
\text { Actone: } F_{2} \mathrm{O} \\
\mathrm{Na}_{2} \mathrm{SO}_{4}: \text { tissue }\end{array}$ & $\begin{array}{c}209 \cdot 0 \\
22.0 \\
298.58\end{array}$ & 529.58 & 1.41 \\
\hline $\begin{array}{l}\text { Visceral } \\
\text { fet }\end{array}$ & $\begin{array}{l}\text { Hexane } \\
\text { icetone: } \mathrm{H}^{\mathrm{O}} \\
\mathrm{Na}_{2} \mathrm{SO}_{4}: \text { tissuo }\end{array}$ & $\begin{array}{l}843.0 \\
111.0 \\
145.67\end{array}$ & 1099.67 & 2.99 \\
\hline Blood & $\begin{array}{l}\text { Hcrane } \\
\text { Acetone: } \mathrm{I}_{2} \mathrm{O}\end{array}$ & $\begin{array}{r}4.0 \\
10.0\end{array}$ & 14.0 & 0.04 \\
\hline Urine it 1 & & 1058.0 & 1058.0 & 2.83 \\
\hline Urine $\# 2$ & & 2124.0 & 2124.0 & $5 \cdot 78$ \\
\hline Urine & & 2197.0 & 2197.0 & 5.98 \\
\hline Teces 形 1 & $\begin{array}{l}\text { Hezane } \\
\text { icetone: } \mathrm{H}_{2} \mathrm{O} \\
\text { ia }_{2} \mathrm{SO}_{4}: \text { foces }\end{array}$ & $\begin{array}{c}717.0 \\
392.0 \\
4428.30\end{array}$ & $5537 \cdot 30$ & 15.10 \\
\hline Feces ff 2 & $\begin{array}{l}\text { iiexane } \\
\text { Acetone: } \mathrm{H}_{2} \mathrm{O} \\
\mathrm{IJa}_{2} \mathrm{SO}_{4}: \text { Ieces }\end{array}$ & $\begin{array}{c}337.0 \\
81.0 \\
684.95\end{array}$ & 1002.95 & 2.73 \\
\hline
\end{tabular}


Table 3. (Contd.)

\begin{tabular}{|c|c|c|c|c|}
\hline Source & $\begin{array}{l}\text { Extract } \\
\text { fraction }\end{array}$ & $\begin{array}{l}\text { CPM less } \\
\text { background }\end{array}$ & $\begin{array}{c}\text { Total } \\
\text { CPM }\end{array}$ & $\begin{array}{l}\% \text { of recovered } \\
\text { radioactivity }\end{array}$ \\
\hline $\begin{array}{l}\text { Contesnts in } \\
\text { Gastrointes- } \\
\text { tinal tract }\end{array}$ & $\begin{array}{l}\text { Hexane } \\
\text { Acetone: } \mathrm{H}_{2} \mathrm{O} \\
\mathrm{Na}_{2} \mathrm{SO}_{4} \text { : contents }\end{array}$ & $\begin{array}{c}148.0 \\
178.0 \\
\text { s } 2851.47\end{array}$ & 3177.47 & 8.65 \\
\hline $\begin{array}{l}\text { Respiratory } \\
\mathrm{CO}_{2}\end{array}$ & $\mathrm{BaCO}_{3}$ & 397.8 & 397.8 & 1.08 \\
\hline Carcass & $\mathrm{BaCO}_{3}$ & 12120.0 & 12120.0 & 30.3 \\
\hline Equipment & & 5602.0 & 5602.0 & 16.1 \\
\hline \multicolumn{3}{|l|}{ Total } & 36695.0 & \\
\hline \multicolumn{3}{|c|}{$\mathrm{C}^{14}$-endosulfan standard } & 195000.0 & \\
\hline
\end{tabular}

Percont recovered $=21 \%$ 


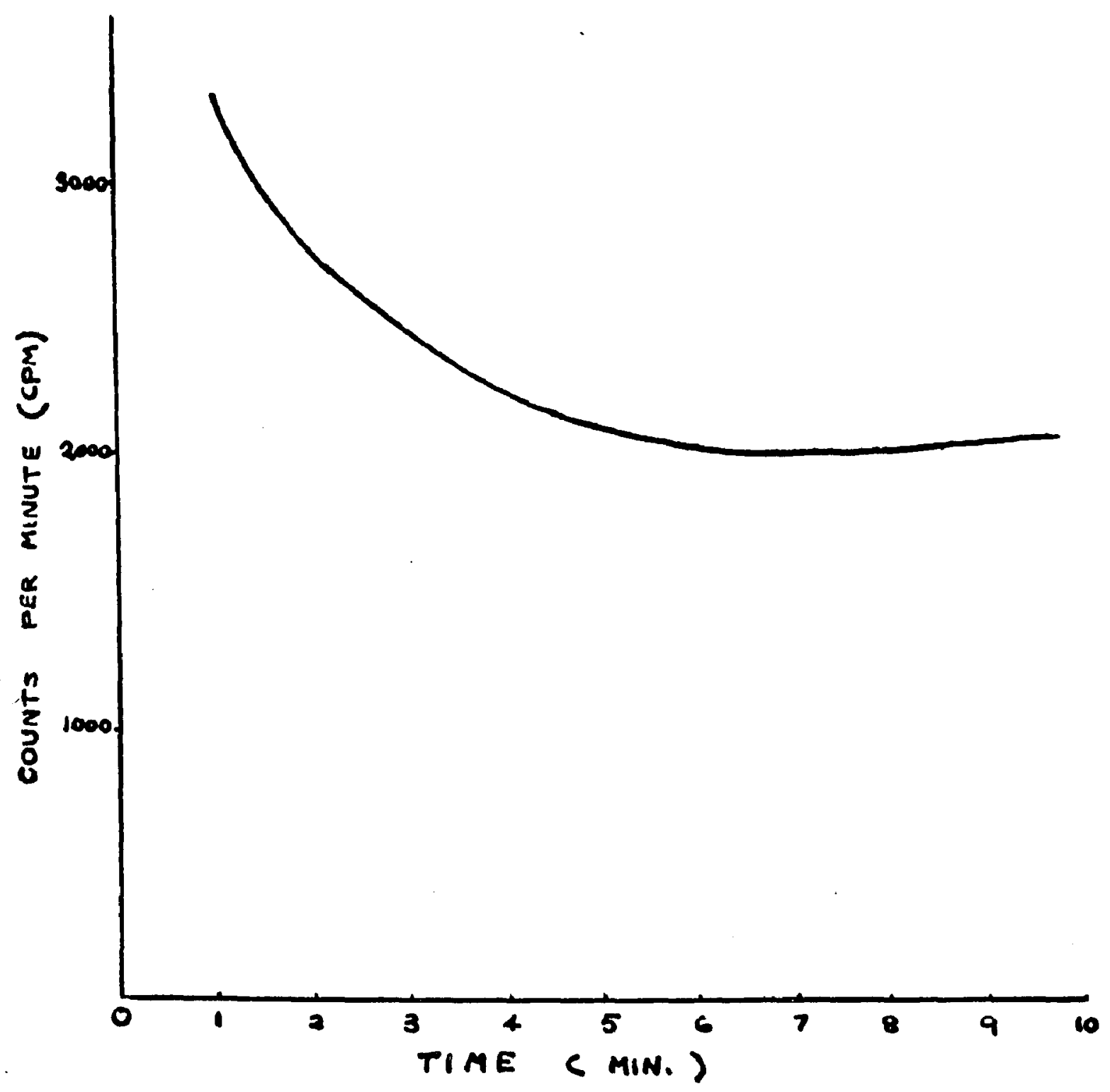

Figure 11. Deorease in radioaotivity as shown by liquid scintillation speotrometer due to settling of the sample in the vial. ( $\mathrm{Na}_{2} \mathrm{SO}_{4}$ : Peces) 
Results of Gas chronatographic analysis of the 12-hour studies of nice fed with 0.30 me purified endosulfan are summarized in Table 4. Oxidized endosulfan ( the cyclic sulfate of endosulfin ) was detected in the liver, kidney, small intestine, muscle, and visceral fat extracts. Large amounts of oridized endosulfan were found in the liver, small intestine, and visceral fat extracts, while only a trace of it was found in the muscle and kidney extracts. It is possible that oxidized endosulfan was found in the ruscle and kidney extracts due to fatty tissue surrounding those organs since in later extractions of these organs from other tost aninals no oxidized endosulfan was found. The low- and high-melting isomers of endosulfan were found in the stonach as well as in small intestine extracts. Some of the stomachs contained undigestod food at the time of axtraction and this may have resulted in the detection of both low- and highmelting isomers. Feces in the small intestine were included in the snall intestine extracts, which contained large amounts of oxidized endosulfan detected with gas chronatography.

Neither of the isomers nor their metabolites were detected in the blood extracts.

Urine and feces of thase mice vere extracted using the hexane-acetone procodure. Neither isomer of endosulfan nor their metabolites were detected when the radium detector was used. When the tritium detector was used, gas chromatograms 
Table 4. - Electron capture gas chromatographic analysis of organ extracts from mice sacrificed 12 hours following ingestion of $0.30 \mathrm{mg}$ purified endosulfan.

\begin{tabular}{|c|c|c|c|c|c|c|}
\hline Organs & $\begin{array}{l}\text { IJPP } \\
\text { isomer }\end{array}$ & $\begin{array}{l}\text { EllP } \\
\text { isomer }\end{array}$ & $\begin{array}{c}\text { Endosulfan } \\
\text { Ether }\end{array}$ & $\begin{array}{c}\text { Endosulfan } \\
\text { Sulfate }\end{array}$ & $\begin{array}{l}\text { Endosulfan } \\
\text { Alcohol }\end{array}$ & Wetabolite \\
\hline Iiver & - & - & - & ++ & - & - \\
\hline Kidney & - & - & - & * & - & - \\
\hline Stomach & ++ & ++ & - & - & - & - \\
\hline $\begin{array}{l}\text { Small } \\
\text { Intestine }\end{array}$ & $e^{++}$ & ++ & - & ++ & - & - \\
\hline Nuscle & - & - & - & * & - & - \\
\hline $\begin{array}{c}\text { Visceral } \\
\text { Fat }\end{array}$ & - & - & - & ++ & - & - \\
\hline Blood & - & - & - & - & - & - \\
\hline Urine & - & - & - & - & - & ++ \\
\hline Feces & ++ & ++ & - & ++ & ++ & - \\
\hline
\end{tabular}

$$
\begin{aligned}
& \text { Symbols: }++=\text { readily detectable by gas chromatography. } \\
& *=\text { trace-between } 0.01-0.02 \text { ng endosulfan sulfate } \\
&-=\text { undetectable-less than } 0.01 \text { ng endosulfan } \\
& \text { sulfate; } 0.02 \mathrm{ng} \text { purified endosulfan; } 0.005 \mathrm{ng} \text { endo- } \\
& \text { sulfan ether; and } 0.4 \mathrm{ng} \text { endosulfan alcohol. } \\
& \text { LlPP } \quad=\text { Low-melting point } \\
& \text { HIP } \quad \text { - High-melting point }
\end{aligned}
$$


showed all isomers of endosulfan, endosulfan alcohol and oxidized endosulfan in the fecal extracts. In urine extracts, a netabolite was found with the tritium detector which has the same retention time as endosulfan alcohol. These results indicate that the tritium detector is considerably more sensitive than the radium detector. Operatins temperatures of both systems were the same throughout the investigation : the detector at $220^{\circ} \mathrm{C}$, the column at $210^{\circ} \mathrm{C}$, and the injection block temperature at $225^{\circ} \mathrm{C}$.

The results of paper chromatographic separation of these organs were not conclusive. Not all spots obtained from the organ extracts were readily detectable and they were whitish in color instead of the usual dark brown $\Lambda g C l$ hue as obtained from the endosulfan isomer standards.

From the preliminary studies, it was determined that $15 \mathrm{mg}$ of purified endosulfan per kilogram of body weight was the maximum tolerated dosage for this strain of white nice. At $20 \mathrm{mg} / \mathrm{kg}$, most of the test mice did not survive the 24-hour period following ingestion of the treated food. From this study the $I D_{10}$ of purified endosulfan was estimated to be $15-20 \mathrm{mg} / \mathrm{kg}$ of body weight for the laboratory mouse.

In the 24-hour studies of mice fed $0.30 \mathrm{mg}$ of puriried endosulfan, the results of gas chromatogruphic analysis of orcan extracts vere identical to those of the 12-hour studies (rable 5). Urine and feces rere cxiructed with the hexanc-acotone wethod and 
tire residues were identified with gas chronatography, paper chromatograihy, and thin-leyer chronatospaphy. These three methods failed to show any isomers of endosulfan or its netabolic products in urine or feces extracts. lhis may be due to the fact that some of the metabolic products are insoluble in hexane and remained in the acetone-water portion. This was partially confinmed by the results from the metabolism of $\mathrm{C}^{14}$-endosulfen in mice. The acctonewater portion of urine extracts from mice fed $\mathrm{C}^{14}$-endosulfan showed tho highest radioactivity (Table 2 and 3). Vith the tritium detector, a metabolic product which has same retention time as endosulfan alcohol was detected in the urine cxtracts. Howevor, it is not believed that the urine metabolite is endosulfan alcohol for two reasons: (I) Its peak shape is not characteristic of the alcohol, and (2) theoretically the alcohol silould not be urino- or vater-soluble.

All isomers of endosulfan, endosulfan alcohol and oxidized endosulfan were detected in the fecal extracts. Wost of the radioactivity in fecal extracts obtained from mice which were fed $\mathrm{c}^{14}$-endosulfan was in the sodiun sulfate-feces portion (Tables 2 and 3 ).

In the netabolism studies of mice fed with $0.30 \mathrm{me}$ of low-neltine isoner (Table 6), only the low-melting isoner was detected in extract; of the stomach, sull intestine, and foces. The oridizod endosulfan vas detected by gas chromatograpiny in the liver, silail intestinc, visceral fat, und focul extracts. 
Table 5. - Electron capture gas chromatographic analysis of organ extracts from mice sacrificed 24 hours following ingestion of $0.30 \mathrm{mg}$ purified endosulfan.

\begin{tabular}{|c|c|c|c|c|c|c|}
\hline Organs i & $\begin{array}{l}\text { LiP } \\
\text { isomer }\end{array}$ & $\begin{array}{l}\text { HIP } \\
\text { isomer }\end{array}$ & $\begin{array}{c}\text { Endosulfan } \\
\text { Ether }\end{array}$ & $\begin{array}{c}\text { Endosulfan } \\
\text { Sulfate }\end{array}$ & $\begin{array}{c}\text { Endosulfan } \\
\text { Alcohol }\end{array}$ & Netabolite \\
\hline Liver & - & - & - & ++ & - & - \\
\hline Kidney & - & - & - & * & - & - \\
\hline Stomach & ++ & ++ & - & - & - & - \\
\hline $\begin{array}{l}\text { Small } \\
\text { Intestine }\end{array}$ & $e^{++}$ & ++ & - & $+t$ & - & - \\
\hline ifuscle & - & - & - & * & - & - \\
\hline Fat & - & - & - & ++ & - & - \\
\hline Blood & - & - & - & - & - & - \\
\hline Urino & - & - & - & - & - & ++ \\
\hline Feces & ++ & ++ & - & ++ & ++ & - \\
\hline
\end{tabular}

Symbols: Same as: Table 4. 
Table 6. - Eilectron capture gas chromatorgughic analysis of orcan extracts from mice sacrificed 24 hours following ingestion of $0.30 \mathrm{me}$ low-melting point isoner.

\begin{tabular}{|c|c|c|c|c|c|c|}
\hline Organs & $\begin{array}{l}\text { LiP } \\
\text { isomer }\end{array}$ & $\begin{array}{l}\text { HIP } \\
\text { isomer }\end{array}$ & $\begin{array}{l}\text { Endosulfan } \\
\text { Ether }\end{array}$ & $\begin{array}{c}\text { Andosulfan } \\
\text { Sulfate }\end{array}$ & $\begin{array}{l}\text { Indosulfan } \\
\text { Alcohol }\end{array}$ & $\because \because e t a b o l i t$ \\
\hline Liver & - & - & - & ++ & - & - \\
\hline Kidnoy & - & - & - & * & - & - \\
\hline Stomach & ++ & - & - & - & - & - \\
\hline $\begin{array}{l}\text { Small } \\
\text { Intestine }\end{array}$ & $e^{++}$ & - & - & ++ & - & - \\
\hline Wuscle & - & - & - & * & - & - \\
\hline $\begin{array}{l}\text { Visceral } \\
\text { Fat }\end{array}$ & - & - & - & ++ & - & - \\
\hline Blood & - & - & - & - & - & - \\
\hline Urine & - & - & - & - & - & ++ \\
\hline Feces & ++ & - & - & ++ & ++ & - \\
\hline
\end{tabular}

Symbols: Same as Table 4 . 
The paper chromatograms did not show a śood resolution. Tho spots obtained from organ extracts of test animals and control animals appeared whitish in color, as opposed to the spots produced by isomer standards, which were dark-brown in color.

In the 24-hour studies of mice fed 0.30mg of high-meltins isomer, fas chronatogrephic analysis showed oxidized ondosulfan in the liver, kidney, sall intestine, muscle, and visceral fat extracts ( Table 7). Larse amounts of oxidized endosulfan vere detected in the liver, small intestine, and visceral fat oxtracts. The oxidized endosulfan found in kidnoy and muscle extracts may heve been due to attached fat tissue. Later in tisis investigation when the nethods of obtaining samples improved, oxidized endosulfan was not detected in the kidney and muscle extracts.

In urine extracts, the high-melting isomer was detected by gas chromatography. This may have boen due to contanination by the mouse in the metabolism care. Then a mouse holds insecticidetreated food between his front feet, his feet bccone contaminated. Then, in walking around the metabolism cage, the mouse contaminatos the cace, which in turm night contaminate any urine which concs in contact with the floor of the case. In later experiments, the aninal feet were rinsed with acetone prior to housing in the metabolism caco. is a rosult, none oi the isomers of ondosulfan wore detceted in the urine stracts. A metabolic product which has same retention time as endosulfon alcohol vas detectod by Eas chronatocraph ocuipped with the tritium detector but not when the radiun detector was uscd. In the focal oxtracts larse amounts 
of high-melting isomer, endosulfan alcohol and oxidized endosulfan were detected.

Table 7. - Electron capture gas chromatographic analysis of organ extracts from mice sacrificed 24 hours followine ingestion of 0.30 me high-melting point isomer.

\begin{tabular}{|c|c|c|c|c|c|c|}
\hline Organs & $\begin{array}{l}\text { LMP } \\
\text { isomer }\end{array}$ & $\begin{array}{l}\text { HWP } \\
\text { isomer }\end{array}$ & $\begin{array}{c}\text { Endosulfan } \\
\text { Etber }\end{array}$ & $\begin{array}{c}\text { Endosulfan } \\
\text { Sulfate }\end{array}$ & $\begin{array}{l}\text { Endosulfan } \\
\text { Alcohol }\end{array}$ & Hetabolit \\
\hline Liver & - & - & - & ++ & 一 & - \\
\hline Kidney & - & - & - & * & - & - \\
\hline Stomach & - & - & - & - & - & - \\
\hline $\begin{array}{l}\text { Small } \\
\text { Intestine }\end{array}$ & - & ++ & - & ++ & - & - \\
\hline Nusclo & - & - & - & * & - & - \\
\hline $\begin{array}{l}\text { Visceral } \\
\text { Fat }\end{array}$ & - & - & - & ++ & - & - \\
\hline Blood & - & - & - & - & - & - \\
\hline Urine & - & - & - & - & - & ++ \\
\hline Feces & - & ++ & - & ++ & ++ & - \\
\hline
\end{tabular}

Symbols: Same as Table 4. 
Table 8. - Electron capture gas chromatographic analysis of organ extracts from mice sacrificed after 7 days on $10 \mathrm{ppm}$ endosulfan treated food.

\begin{tabular}{|c|c|c|c|c|c|c|}
\hline Organs & $\begin{array}{l}\text { IITP } \\
\text { isomer }\end{array}$ & $\begin{array}{l}\text { HlllP } \\
\text { isomer }\end{array}$ & $\begin{array}{c}\text { Endosulfan } \\
\text { Ither }\end{array}$ & $\begin{array}{l}\text { Endosulfan } \\
\text { Sulfate }\end{array}$ & $\begin{array}{c}\text { Endosulfan } \\
\text { Alcohol }\end{array}$ & Metabolit \\
\hline Liver & - & - & - & ++ & - & - \\
\hline Kidney & - & - & - & - & - & - \\
\hline Stomach & ++ & ++ & - & - & - & - \\
\hline $\begin{array}{l}\text { Small } \\
\text { Intestine }\end{array}$ & $e^{+t}$ & ++ & - & ++ & - & - \\
\hline Muscle & - & - & - & - & - & - \\
\hline $\begin{array}{l}\text { ViscereI } \\
\text { Fat }\end{array}$ & - & - & - & ++ & - & - \\
\hline Urine & - & - & - & - & - & ++ \\
\hline Feces & ++ & ++ & - & ++ & ++ & - \\
\hline
\end{tabular}

Symbols: Same as Table 4. 
Table 9. - Electron capture gas chromatographic analysis of organ extracts from mice sacrificed after 14 days on $10 \mathrm{ppm}$ endosulfan treated food.

\begin{tabular}{|c|c|c|c|c|c|c|}
\hline Organs & $\begin{array}{l}\text { INPP } \\
\text { isomer }\end{array}$ & $\begin{array}{l}\text { HRIP } \\
\text { isomer }\end{array}$ & $\begin{array}{c}\text { Endosulfan } \\
\text { Ether }\end{array}$ & $\begin{array}{l}\text { Endosulfan } \\
\text { Sulfate }\end{array}$ & $\begin{array}{c}\text { Endosulfan } \\
\text { Alcohol }\end{array}$ & Netabolit \\
\hline Liver & - & - & - & ++ & - & - \\
\hline Kidney & - & - & - & - & - & - \\
\hline Stomach & ++ & ++ & - & - & - & - \\
\hline $\begin{array}{l}\text { Small } \\
\text { Intestine }\end{array}$ & $e^{++}$ & ++ & - & ++ & - & - \\
\hline Fuscle & - & - & - & - & - & - \\
\hline $\begin{array}{l}\text { Visceral } \\
\text { Fat }\end{array}$ & - & - & - & ++ & - & - \\
\hline Urine & - & - & - & - & - & ++ \\
\hline Feces & ++ & ++ & - & ++ & ++ & - \\
\hline
\end{tabular}

Symbols : Same as Table 4. 
Table 10. - Electron capture gas chromatographic analysis of organ extracts from mice sacrificed after 21 days on $10 \mathrm{ppm}$ endosulfan treated food.

\begin{tabular}{|c|c|c|c|c|c|c|}
\hline Organs $i$ & $\begin{array}{l}\text { LlifP } \\
\text { isomer }\end{array}$ & $\begin{array}{l}\text { HilP } \\
\text { isomer }\end{array}$ & $\begin{array}{c}\text { Endosulfan } \\
\text { Ether }\end{array}$ & $\begin{array}{l}\text { Endosulfan } \\
\text { Sulfate }\end{array}$ & $\begin{array}{l}\text { Endosulfan } \\
\text { Alcohol }\end{array}$ & Hetabolite \\
\hline Liver & - & - & - & ++ & - & - \\
\hline Kidney & - & - & - & - & - & - \\
\hline Stomach & ++ & ++ & - & - & - & - \\
\hline $\begin{array}{l}\text { Small } \\
\text { Intestine }\end{array}$ & $e^{++}$ & ++ & - & ++ & - & - \\
\hline Wuscle & - & - & - & - & - & - \\
\hline $\begin{array}{l}\text { Visceral } \\
\text { Fat }\end{array}$ & - & - & - & ++ & - & - \\
\hline
\end{tabular}

Symbols : Same as Pable 4. 
Table 11. - Electron capture gas chromatographic analysis of organ extracts from mice sacrificed after 28 days on $10 \mathrm{ppm}$ endosulfan treated food.

\begin{tabular}{|c|c|c|c|c|c|c|}
\hline Organs & $\begin{array}{l}\text { IllP } \\
\text { isomer }\end{array}$ & $\begin{array}{l}\text { HIIP } \\
\text { isomer }\end{array}$ & $\begin{array}{c}\text { Endosulfan } \\
\text { Ether }\end{array}$ & $\begin{array}{l}\text { Endosulfan } \\
\text { Sulfate }\end{array}$ & $\begin{array}{l}\text { Endosulfan } \\
\text { Alcohol }\end{array}$ & Setabolit \\
\hline Liver & - & - & - & ++ & - & - \\
\hline Kidney & - & - & - & - & - & - \\
\hline Stomach & ++ & ++ & - & - & - & - \\
\hline $\begin{array}{l}\text { Small } \\
\text { Intestine }\end{array}$ & $e^{+t}$ & ++ & - & ++ & - & - \\
\hline Vuscle & - & - & - & - & - & - \\
\hline $\begin{array}{l}\text { Visceral } \\
\text { Fat }\end{array}$ & - & - & - & ++ & - & - \\
\hline Urine & - & - & - & - & - & ++ \\
\hline Feces & ++ & ++ & - & ++ & ++ & - \\
\hline
\end{tabular}

Symbols : Same as Table 4. 
Table 12. - Lilectron capture gas chromatographic analysis of organ extracts from mice sacrificed after 35 days on $10 \mathrm{ppm}$ ondosulfan treated food.

\begin{tabular}{|c|c|c|c|c|c|c|}
\hline Organs I & $\begin{array}{l}\text { LriP } \\
\text { isomer }\end{array}$ & $\begin{array}{l}\text { HIIP } \\
\text { isomer }\end{array}$ & $\begin{array}{c}\text { Endosulfan } \\
\text { Ether }\end{array}$ & $\begin{array}{l}\text { Endosulfan } \\
\text { Sulfate }\end{array}$ & $\begin{array}{l}\text { Endosulfan } \\
\text { Alcohol }\end{array}$ & Metabolite \\
\hline Liver & - & - & - & ++ & - & - \\
\hline Kidney & - & - & - & - & - & - \\
\hline Stomach & - & - & - & - & - & - \\
\hline $\begin{array}{l}\text { Small } \\
\text { Intestine }\end{array}$ & $e^{++}$ & ++ & - & ++ & - & - \\
\hline Ifuscle & - & - & - & - & - & - \\
\hline $\begin{array}{l}\text { Visceral } \\
\text { Fat }\end{array}$ & - & - & - & ++ & - & - \\
\hline Brain & - & - & - & - & - & - \\
\hline
\end{tabular}

Symbols : Same as Table 4. 
Table 13. - Electron capture gas chromatographic analysis of orgen extracts from mice sacrificed after 42 days on $10 \mathrm{ppm}$ endosulfan treated food.

\begin{tabular}{|c|c|c|c|c|c|}
\hline Organs & $\begin{array}{l}\text { IfIP } \\
\text { isomer }\end{array}$ & $\begin{array}{l}\text { HIRP } \\
\text { isomer }\end{array}$ & $\begin{array}{l}\text { Endosulfan } \\
\text { Ether }\end{array}$ & $\begin{array}{l}\text { Endosulfan } \\
\text { Sulfate }\end{array}$ & $\begin{array}{l}\text { Endosulfan } \\
\text { Alcohol }\end{array}$ \\
\hline Liver & - & - & - & ++ & - \\
\hline Kidney & - & - & - & - & - \\
\hline Stomach & - & - & - & - & - \\
\hline $\begin{array}{l}\text { Small } \\
\text { Intestine }\end{array}$ & ++ & ++ & - & ++ & - \\
\hline lfuscle & - & - & - & - & - \\
\hline $\begin{array}{l}\text { Visceral } \\
\text { Fat }\end{array}$ & - & - & - & ++ & - \\
\hline Brain & - & - & - & - & - \\
\hline
\end{tabular}

Symbols : Same as Table 4. 
Table 14. - Electron capture gas chromatogrephic analysis of organ extracts from mice sacrificed after 49 days on $10 \mathrm{ppm}$ treated food.

\begin{tabular}{|c|c|c|c|c|c|}
\hline Organs & $\begin{array}{l}\text { LivP } \\
\text { isomer }\end{array}$ & $\begin{array}{l}\text { Hi.P } \\
\text { isomer }\end{array}$ & $\begin{array}{c}\text { Endosulfan } \\
\text { Ether }\end{array}$ & $\begin{array}{c}\text { Endosulfan } \\
\text { Sulfate }\end{array}$ & $\begin{array}{l}\text { Endosulfan } \\
\text { Alcohol }\end{array}$ \\
\hline Liver & - & - & - & ++ & - \\
\hline Kidney & - & - & - & - & - \\
\hline Stomach & - & - & - & - & - \\
\hline $\begin{array}{l}\text { Small } \\
\text { Intestine }\end{array}$ & ++ & ++ & - & ++ & - \\
\hline Ifuscle & - & - & - & - & - \\
\hline $\begin{array}{l}\text { Visceral } \\
\text { Fat }\end{array}$ & - & - & - & ++ & - \\
\hline Brain & - & - & - & - & - \\
\hline
\end{tabular}

Symbols : Same as Table 4. 


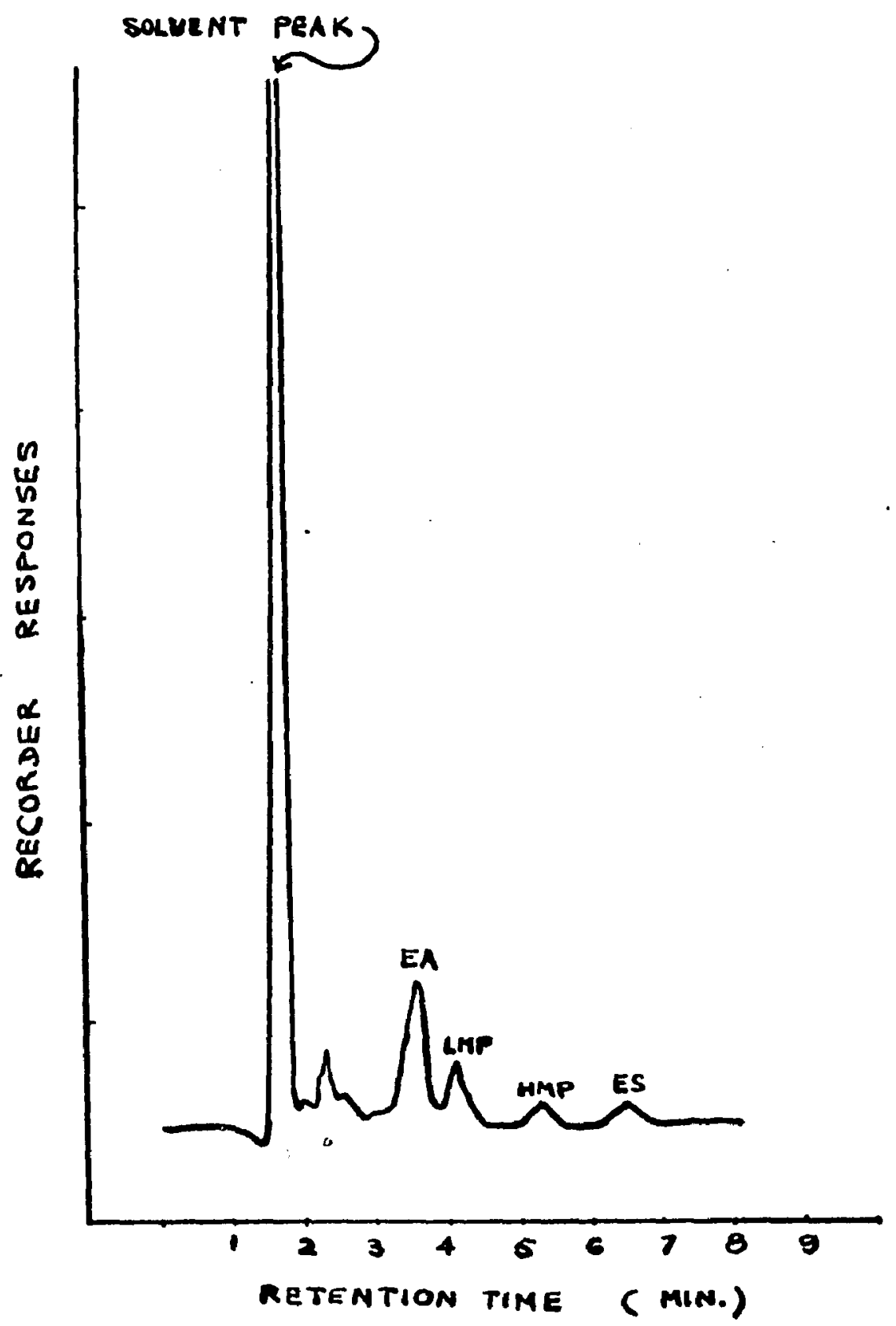

Figure 12. A ohromatogram trace of $2 \mu l$ of fecal extracts from a female mouse after ingesting $10 \mathrm{ppm}$ endosulfan treated food for 28 days.

$$
\text { Deteotor : Tritium }
$$

Temperature injeotion : $225^{\circ} \mathrm{C}$

Column temperature :210 $\mathrm{C}$

Deteotor temperature $: 222^{\circ} \mathrm{C}$ 
Results of gas chromatographic analysis of organ extracts from mice fed $10 \mathrm{ppm}$ of purified endosulfan for $7,14,21,28,35$ 42 and 49 days are summarized in Tables 8, 9, 10, 11, 12, 13 and 14. The oxidized endosulfan was detected in the liver and visceral fat extracts of all ten mice. Less oxidized endosulfan was found in these organs than was found in the liver and visceral fat of mice fed with $0.30 \mathrm{mg}$ purified endosulfan for 12 and 24-hour studies. The oxidized endosulfan found in organs of test mice fed $10 \mathrm{ppm}$ decreased as the investigation progressed. This can not be explained on the basis of what is presently known of cyclodiene insecticide metabolism and storage in mammalian tissue.

The low- and high-melting isomers of endosulfan were detected in the stomach extracts of mice fed 10 pom endosulfan for 7,14 , 21 , and 28 days. It is possible that prior to the test the mice examined at 35, 42, and 49 days did not oat the treated food immediately prior to dissection; otherwise the results should have been the same as in mice examined at $7,14,21$, and 28 days. Neither of the endosulfan isomers nor the metabolic products of endosulfan were detected in the brain extracts. Apparently the same matabolic product which was doscribed as found in the 24 hour tests having the endosulfan alcohol retention time was detected in urine extracts of the mice fed $10 \mathrm{ppm}$. Both isomers and all the metabolites including oxidized endosulfan in large anounts, were found in benzene extracts of feces from mice fed $10 \mathrm{ppm}$ for 7,14 and 28 days ( Figure 12 ). 
Thin-la yer chromatographic analysis of both the purified endosulfan and its isomers are summarized in the Table 15 . The $R_{f}$ values: obtained from the thin-layer chromatogram are different from those obtained from the paper chromatograms. The endosulfan alcohol which has the $R_{f}$ value highest in the paper chromatograms is the lowest in the thin-layer chromato grams is the lowest in the thin-layer chromatograms. The thin-layer chromatograms produced more distinctive spots of the organ extracts than those shown on the paper-chromatograms. The spots wich were apparent on the thinlayer chromatograms were scraped from the plate with a razor blade and were separately dropped into screw-cap vials which contained $5 \mathrm{ml}$ glass-distilled hexane. Each vial was shaken and allowed to settle for five minutes and then $5 \mathrm{ul}$ of the hexane portion was injected in the gas chromatograph. The peaks obtained by the thin-layer chromatographic clearup method corresponded with those obtained from the organ extracts before cleamu. 
Table 15. - $R_{f}$ values of technical endosulfan and related derivatives separated by thin-layer chromatography.

\begin{tabular}{lc}
\hline Standard & $\mathrm{R}_{f}^{*}$ \\
\hline Endosulfan Low-llelting Point isomer & $0.16,0.15$ \\
Endosulfan High-lielting Point isomer & $0.6,0.67$ \\
Endosulfan Sulfate & $0.08,0.08$ \\
Endosulfan Alcohol & $0.03,0.03$ \\
\hline
\end{tabular}

* Nobile phase, $96 \%$ heptane in acetone. Stationary phase, Silica Gel. 
Faint, but readily detectable spots were produced on an autoradiogram made from a paper chroms togram which had been spotted with $20 \mu I$ each of the hexane-acetone extracts of various organs from the mice each fed with $0.30 \mathrm{mg} \mathrm{C}^{14}$-endosulfan and sacrificed at the end of 24 hours. Only the stomach extracts showed four definite spots which corresponded to the four components of $\mathrm{c}^{14}$-endosulfan standard. Neither of the isomers of endosulfan nor their metabolic products were found in other organ extracts on the autoradiogram. This may be because insufficient material from each sample ras spotted on paper chromatograms or not enough residue was in the hexane portion of extractions which were used in spotting the paper chromatograms.

An autoradiogram obtained from liver and kidney extracts of a mouse which died after eating $0.6 \mathrm{mg} \mathrm{c}^{14}$-endosulfen over a period of six days produced four spots corresponding to the low and high-melting isomers, endosulfan ether and oxidized endosulfan. The spots obtained from kidney extracts separated nicely unlike the spots produced from liver extracts. The liver extracts produced tailing, but separate spots. It is possible that too much liver extract had been placed on the paper chromatoram. The autoradiogram was placed above the original paper chromatogram and the spots were carefully marked on the paper chromatogram. These spots were then cut from the chromatogram with scissors and extracted with $5 \mathrm{ml}$ hexane. A $5 \mu l$ portion of each spot was injected into the gas chromatograph. The extracted spots corresponded with those obtained from endosulfan 
isomers and their metabolic products. This indicated that in a mouse which died after ingesting endosulfan, liver and kidney contained isomers of endosulfan and their matabolic products including a very small amount of oxidized endosulfan.

In another phase of this study, mice were fed either $0.30 \mathrm{mg}$ purified endosulfan and sacrificed after 12 hours, $0.30 \mathrm{mg}$ high-melting point isomer (sacrificed after 24 hours), or $0.30 \mathrm{mE}$ lowmelting point isomer (sacrificed after 24 hours). When the extracted organs from these mice were analyzed by gas chronatography, the results differed from the autoradiographic results. The only metabolite found vas oxidized endosulfan, which was present in large quantities in liver extracts but only in trace amounts ( $0.02 \mathrm{ng}$ ) in kidney extracts. in animal which detoxifies endosulfan at the same rate in which it is ingested survives.

It appears that when endosulfan is oxidized to the sulfate it is detoxified, and is stored and excreted per se. Further studies are needed with all endosulfan cormponents to learn their fate and toxicity in the mouse.

Daily food consumption of all mice, both test and control, was recorded throughout the investigation. The avcrage daily food consumption of mice eating $10 \mathrm{ppm}$ endosulfan-treated food for 49 days was $4.52 \mathrm{~g}$ for male and $4.41 \mathrm{~g}$ for fenale. íverage daily food consurption of control mice was $4.52 \mathrm{~g}$ (Table 16). 
Table 16. - Average daily food consumption of mice fed 10 ppm endosulfan-treated food and the control food.

\begin{tabular}{|c|c|c|c|c|}
\hline Sex & $\begin{array}{l}\text { Length of } \\
\text { experiment } \\
\text { Days }\end{array}$ & $\begin{array}{l}\text { Initial } \mathrm{it.} \\
(\mathrm{g})\end{array}$ & $\begin{array}{l}\text { Wt. prior } \\
\text { sacrificed } \\
\text { (g) }\end{array}$ & $\begin{array}{l}\text { Average daily } \\
\text { food consumption } \\
\qquad(\mathrm{g})\end{array}$ \\
\hline Wale & $\begin{array}{l}7 \\
14 \\
21 \\
28 \\
35 \\
42 \\
49 \\
28 \\
28\end{array}$ & $\begin{array}{l}17.00 \\
16.80 \\
30.50 \\
16.60 \\
28.30 \\
28.70 \\
27.60 \\
23.80 \\
26.10\end{array}$ & $\begin{array}{c}20.00 \\
21.20 \\
30.70 \\
21.60 \\
31.20 \\
32.80 \\
30.20 \\
- \\
-\end{array}$ & $\begin{array}{l}4.20 \\
4.10 \\
4.30 \\
4.26 \\
4.87 \\
5.10 \\
4.80 \\
4.00 \\
4.86\end{array}$ \\
\hline $\begin{array}{l}\text { Female } \\
\text { Control }\end{array}$ & $\begin{array}{l}7 \\
14 \\
21 \\
28 \\
35 \\
42 \\
49 \\
28 \\
28\end{array}$ & $\begin{array}{l}24.80 \\
22.80 \\
21.80 \\
25.30 \\
22.80 \\
20.80 \\
23.80 \\
23.00 \\
26.30\end{array}$ & $\begin{array}{c}24.50 \\
23.00 \\
23.50 \\
24.80 \\
23.00 \\
22.80 \\
24.50 \\
- \\
-\end{array}$ & $\begin{array}{l}4.27 \\
4.14 \\
4.20 \\
4.30 \\
4.66 \\
4.00 \\
5.30 \\
4.66 \\
4.58\end{array}$ \\
\hline
\end{tabular}




\section{CONCLUSIONS}

From this investigation the following conclusions are dram:

1. Endosulfan fed continuously at $10 \mathrm{ppm}$ in the total dry diet is a sublethal dose to the BALB/CJaxGnilc strain of laboratory mouse.

2. The maxinum tolerated dosage of endosulfan for this strain of mouse was $15 \mathrm{mg} / \mathrm{kg}$, which is the estimated $\mathrm{LD}_{10^{\circ}}$

3. Oxidized endosulfan (the cyclic sulfate) is the only material stored in any tissue of mice fed endosulfan one dose or continuously for 49 days.

4. An unidentified metabolite is found in the urine of mice fed endosulfan which has the same retention timc as endosulfan alcohol by gas chromatography. However, its peak characteristics are not the same and it is not believed to be the alcohol.

5. The two isomers of endosulfan are not completely absorbed from the gastrointestinal tract when adninistered with the food at a sublethal dosage, but are excreted in the feces with the two motabolites, endosulfan sulfate and alcohol.

6. Neither the known metabolites nor isomers of endosulfan are found in blood or brain extracts. A trace of oxidized endosulfan is detected in kidney and muscle extracts but this may be due to small quantities of fat contained in these organs. 
7. Approximately $65 \%$ of the radioactivity was recovered from a mouse fed with $\mathrm{C}^{14}$-endosulfan durinE 24-hour poriod. Recovery from a second mouse whose radioactivity was measured somewhat differently, was only 2l\%. Based on the specific activity (activity/ weight) of the organs and excreta the following sequence was obtained: Feces >visceral fat > urine >liver > small intestine and contents) kidney> brain > respiratory $\left.\mathrm{CO}_{2}\right\rangle$ blood.

8. In the sacrificed mice, a large amount of oxidized endosulfan was detected in the liver and a trace in the kidney. In a mouse that died after eating endosulfan, both isomers of endosulfan, endosulfan alcohol, endosulfan ether and oxidized endosulfan were found in the liver and kidney, indicating that both of these organs enter into the metabolism and excretion of endosulfan. 9. The principal metabolic products of endosulfan in the mouse are the sulfate and alcohol. 


\section{AUTOBIOGIAPHY}

I, Prayoon Deema, was borm July 28, 1933, in Utaradit Province, Thailand, which is about 350 miles north of Bangkok, near the border of Thailand and Laos. In 1940 my parents sent me to Bangkok to attend privat schools. I graduated from Sitabutrabumroong High School in 1952, and then atiended the Kasotasart University for my undereraduate study. The B.SC. deeree in Agriculture, was received in 1957. Since thon I have been employed in the Plant Pest Control Section, Plant Industry Division, Department of Agriculture, Ministry of Agriculture, in Bangkok.

In January, 1960, I received a two-year fellowship from the Agency for International Development to study for a higher degree in the United States. I attended tho University of Arkansas from 1960 until harch 1962, and obtained the M.S. degree in Entomology. Since then I have been working tovard the Ph.D. degree in Intomology, specializing in insect toxicology and pesticide residue analysis. During this time the Ohio Agricultural Experiment Station has employed me as a Research Assistant in the Pesticide Residue Laboratory at the Ohio State University.

I was married in June 1962 to Nualchantra Homgrailars, a Thai student here at the Ohio State University. 
Barnes, W.P., and G.N. Ware. 1964. The absorption and metabolism of $\mathrm{C}^{14}$-labeled endosulfan in the house fly. J. Econ. Entomol. (in press).

Cassil, C.C. 1958. Colorimetric microdetermination of Thiodan residues. Research Dept., Niagara Chem. Div., Food llachinery and Chem. Corp., Richmond, California. Revised July 158 p.

Dawsey, L.H. 1964. Pesticidc reference standards of the Entomological Society of America. Bull. Ent. Soc. Amer. 10(2): 95-103.

Farbwerke Hoechst. 1955. U.S. Pat. 2799685 from April 8,1955. Abstr. in Chem. Abstr. 52:2062g.

Graham, J.R. 1959. Colorimetric microdetermination of Thiodan residues. Research and Development Dept., Niagara Chem. Div., Food Hachinery and Chem. Corp., Hiddleport, New York. Revised June 10. $10 \mathrm{p}$.

Graham, J.R., J. Yaff, T.E. Archer and i. Bevenue. 1964. Thiodan, p. 507-522. In Gunter Zweig, Analytical methods for pesticides, plant growth regulators and food additives. Vol. 2, Insecticides. Academic press, New York.

Hayes, F.r. 1963. Solutes and solvents for liquid scintillation

- counting. Packara Tech. Bull. No. 1. Packard Instrument Co., Inc. Downers Grove, IIIinois. $8 \mathrm{p}$.

Kenaga, E.E. 1963. Commercial and experimental organic insecticides (1963 Revision). Bull. Entomol. Soc. Imer. 9(2): 67-10:

Kovacs, H.F., Jr. 1963. Thin-layer chromatorraphy for chlorinated pesticide residuos analysis. J. iss. Offic. figr. Chem. $46(5): 884-893$. 
Lindquist, D.A., and P.A. Dahm. 1957. Some chemical and biological experiments with Thiodan. J. Econ. Entomol. 50(4): $483-486$.

Haitlen, J.C., K.C. Walker, and W.E. Westlake. 1963. An improved colorimetric method for determining endosulfan (Thiodan) residues in vegetables and beef fat. J. Agr: Food Chem. $I I(5): 416-418$.

liartin, Hubert. 1961. Guide to the chemicals used in crop protection. 4th ed. Pub. 1093. Queen's Printer, Ottawa, Canada. $387 \mathrm{p}$.

litchell, I.C. 1958. Separation and identification of chlorinated organic pesticide by paper chromatography. J. Ass. Offic. Agr. Chem. 41(4):781-817.

Horley, H.V., and H. Chiba. 1964. Thin-layer chromatogriphy for chlorinated pesticide residue analysis without cleanup. J. Ass. Offic. Agr. Chem. 47(2):306-310.

lieimschneider, R. 1963. The chemistry of the insecticides of the diene group. World Rev. Pest Control. 2(4):29-61.

Roth, I.J., L. Leifer, J.J. Hogness, and H.H. Langham. 1948. Studies on the metabolism of radioactive nicotinic acid and nicotinamide in mice. J. Biol. Chem. 176,249-257.

Teylor, A., R.E. Rea, and D.R. Kirby. 1964. An improved procedure for the extraction of organo-chlorine pesticides from animal tissues. Analyst. 89(1060):497-498.

Terranova, A.C., and G.W.Tare. 1963. Studies of endosulfan in bean plants by paper and gas chromatogriphy. J. Econ. Entomol. 56(5):596-599. 
U.S. Department of Agriculture. Agr. Res. Serv. and Fed. Lxt. Serv. 1964. Insecticide Recommendations of the Lntomology Research Division for the control of insects attacking crops, livestock and households for 1964. Agr. Handbook No. 120. 207 p.

Walker, K.C., and H. Beroza. 1963. Thin-layer chronatography for insecticide analysis. J. Ass. Offic. Agr. Chem. 46:250-261.

Van Slyke, D.D., and J. Folch. 1940. Nanometric carbon determination. J.Biol. Chem. 136:509-54l.

Van Slyke, D.D., J. Plazin, and J.R. Veisiger. 1951. Reagents for the Van Slyke-Folch wet carbon combustion. J. Biol. Chem. $191: 299-304$.

Zweig, G., and T.E. Archer. 1960. Determination of Thiodan by gas chromatography. J. Agr. Food. Chem. 8:190-192. 